九州大学学術情報リポジトリ

Kyushu University Institutional Repository

\title{
Geology of the Tansen Group of the Lesser Himalaya in Nepal
}

Sakai, Harutaka

Faculty of Science, Kyushu University

https://doi.org/10.5109/1546083

出版情報：九州大學理學部紀要：Series D, Geology. 25 (1)，pp.27-74，1983-11-15. Faculty of Science, Kyushu University バージョン：

権利関係 : 
Mem. Fac. Sci., Kyushu Univ., Ser. D, Geol., Vol. XXV, No. 1, pp. 27-74, text-figs. 1-23, tables 1-3, plates 3-6, November 15, 1983

\title{
Geology of the Tansen Group of the Lesser Himalaya in Nepal
}

\author{
Harutaka SAKAI
}

\begin{abstract}
This paper is concerned mainly with the stratigraphy of late Palaeozoic, Mesozoic and Cenozoic formations in the southern part of the Lesser Himalayas in the Tansen area, western Central Nepal. The rocks of this area are grouped into two major divisions, the Kali Gandaki Group and the overlying Tansen Group, which are separated by a distinct disconformity.

The Tansen Group consists of five formations, the late Carboniferous to Permian Sisne (250-1000 m thick), late Jurassic to early Cretaceous Taltung $(250 \mathrm{~m})$, probably Cretaceous Amile $(230 \mathrm{~m})$, middle to late Eocene Bhainskati $(160 \mathrm{~m})$, and probably early Miocene Dumri $(725 \mathrm{~m})$, in ascending order, the former three represent the Gondwanas.

The Sisne Formation comprises diamictite and black shale of glacial influence, and is correlated with the glaciofluvial Lower Gondwanas, the Talchir Boulder Beds in the Indian Peninsula and the Blaini Boulder Beds in the Kumaon Lesser Himalaya. It is disconformably overlain by the Taltung Formation with the basal conglomerate, the Charchare Conglomerate. The Taltung represents an upward-fining fluvial facies characterized by cyclic sedimentation in the lower part and rhythmic one in the upper part, and yields plant fossils of the Upper Gondwanas indicating late Jurassic to early Cretaceous age. In the basal part, basaltic lavas attaining altogether $200 \mathrm{~m}$ in thickness are intercalated and have supplied enormous amounts of pebbles to the Charchare Conglomerate. These lavas are compared with the Rajmahal Traps of the eastern Indian Peninsula. The Amile Formation, which rests disconformably on the Taltung, is composed of quartzose sandstone and lesser amounts of shale accompanying bioturbated siltstone and limestone which yield poorly preserved corals and molluscs. The sandstones of the lower part are mottled with ferruginous matter. This formation is interpreted as the coastal plain to intertidal sediments. The Amile is conformably followed by the Bhainskati Formation which is made up of black shale and is accompanied in the lower part with many, thin, calcareous interbeds yielding foraminifers of middle Eocene age along with abundant marine molluses and some vertebrates. In the uppermost part are oolitic hematite containing molluses, redpurple and green mottled shale. This formation is correlated with the Subathu of the Simla and Garhwal Himalaya. The Dumri Formation is a thick series of fluvial deposits consisting interbeds of sandstone and lesser amounts of purple and green shale, and overlies the Bhainskati with a disconformity. The sandstones become much predominant and massive upwards. No fossils available for age determination were obtained, but the lithologic sequence of this formation shows close resemblance to the Dagshai of the Simla-Garhwal Himalaya.

The Tansen Group is disconformably underlain by the Kali Gandaki Group which consists of the Angha Khola Formation $(3000 \mathrm{~m}+$ ) below and the Kerabari Formation $(2000 \mathrm{~m})$ above. The Angha Khola is alternating
\end{abstract}

Manuscript received August 11, 1983. 
beds of purple and green shale with dolomite bands, pinkish quartzose sandstone, arenaceous oolitic dolomite and dolomitic stromatolites. It shows sedimentary facies of a fluvial-sabkha-intertidal flat association. The Kerabari is composed of monotonous thick beds of dolomite with interbeds of stromatolite and oolite, and some thin bands of chert. It is referable to the deposits of a supratidal sabkha to a very shallow sea, mostly intertidal flat environments. As the upper part of the Kerabari includes many carbonaceous seams occasionally containing small plant remains, the Kerabari possibly includes Palaeozoic rocks. The Angha Khola may range down into the Precambrian.

The Tansen Group is embraced in a doubly plunging synclinorium separated from the Kali Gandaki Group by a boundary fault, and is covered by a Klippe of the Kali Gandaki accompanied with a pronounced rupture zone in the central part. It is deformed by folds and faults. The former is of open, southerly verging, asymmetric chevronshape, and the latter is longitudinal or bedding faults of an upthrust sense. In the southern flank of the central area, the Tansen Group forms an imbricate structure. These deformation were taken place after the deposition of the early Miocene Dumri Formation, and no intense diastrophism occurred during the deposition of the Kali Gandaki and the Tansen Groups, except epeirogenic movements that resulted in disconformities beneath the Sisne, Taltung, Amile and the Dumri Formations.

\section{Contents}

Page

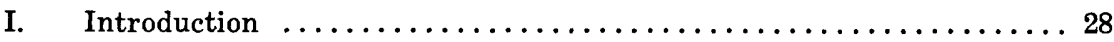

II. Geological Setting and General Geology ................ 30

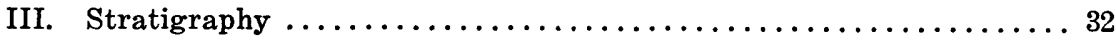

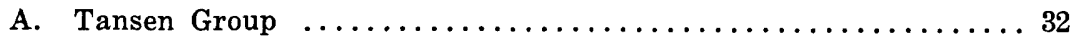

1. Sisne Formation $\ldots \ldots \ldots \ldots \ldots \ldots \ldots \ldots \ldots \ldots \ldots \ldots \ldots \ldots$

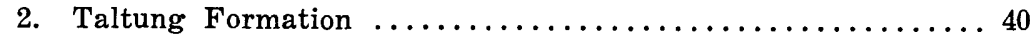

3. Amile Formation $\ldots \ldots \ldots \ldots \ldots \ldots \ldots \ldots \ldots \ldots \ldots \ldots$

4. Bhainskati Formation .................... 53

5. Dumri Formation ........................ 57

B. Kali Gandaki Group ........................ 59

1. Angha Khola Formation $\ldots \ldots \ldots \ldots \ldots \ldots \ldots \ldots \ldots \ldots \ldots \ldots$

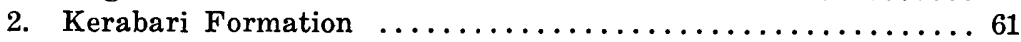

3. Sedimentary Facies $\ldots \ldots \ldots \ldots \ldots \ldots \ldots \ldots \ldots \ldots \ldots \ldots \ldots \ldots$

4. Geologic Age and Correlation ................. 63

IV. Geologic Structure ......................... 65

A. Boundary faults between the Tansen Group and the

Kali Gandaki Group .........................667

B. Structural relationship between the Palpa Klippe and the subjacent Tansen Group ......................68

C. Geologic Structure of the Tansen Group $\ldots \ldots \ldots \ldots \ldots \ldots \ldots$

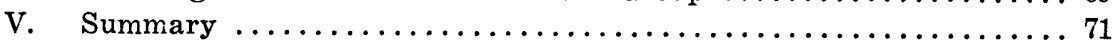

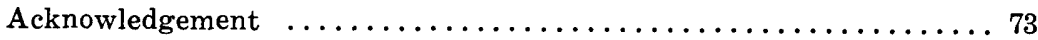

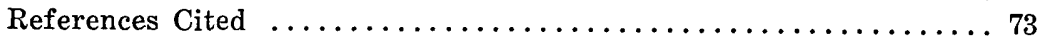

\section{Introduction}

I was dispatched to Nepal as a member of Japan Overseas Cooperation Volunteers under the agreement of technical co-operation between Nepalese and 
Japanese Governments for the promotion of science and land development in Nepal. I worked as a lecturer in the Department of Geology, Trichandra Campus, Tribhuvan University at Kathmandu for three years from 1980 to 1983 . I attempted to undertake field investigations of some area of the Lesser Himalayas in order to make contributions to the geology of Nepal, and chose the Tansen area for the study. The field work was made for myself while I was free from the teaching work in the University.

The Tansen area belongs to the southern part of the Lesser Himalayan Range to the south of Riri Bazar in the middle reaches of the Kali Gandaki river, western Central Nepal.

More than ten papers among others which dealt with the geology of the Lesser Himalayas of the Central and Western Nepal are more or less directly related with the Tansen area. Those are of Hagen (1969), Fuchs \& Frank (1970), Frank and Fuchs (1970), Singh (1973), Ota \& Akiba (ed. 1973), Remy (1975), Sharma (1977, 1980), Fuchs (1980), Mascle (1980), and Arita \& Yoshida (1982). Many of these geological reconaissance surveys are, however, mainly concerned with the geologic structure of a regional-scale and the divisions of tectonic zones and major lithologic units. In these papers a large number of lithologic units or stratigraphic formation names have been proposed, or introduced from other distant places of the Kumaon and Simla-Garhwal Lesser Himalayas in India on the basis of lithologic similarities. However, these units or formations are established often without the designation of the type sections and the stratoboundaries. Even in the cases provided with palaeontological evidence, although fossils are known from only several localities in the Nepal Lesser Himalayas, the stratigraphic sequences are not defined clearly and the areal geology are not mapped.

Under these circumstances, I tried to make a detailed large-scale mapping of the Tansen area and to establish the stratigraphy which would become a standard sequence in the Nepal Lesser Himalayas. As the results, the geological map of the Palpa (Tansen) district was completed. This is the first report of the results of my investigations of this area and describes the stratigraphy of the Tansen Group which ranges in age from late Carboniferous-Permian to early Miocene. Descriptions of fossils obtained from the Tansen Group and of the detailed stratigraphy of the underlying Kali Gandaki Group will be given in another paper in near future.

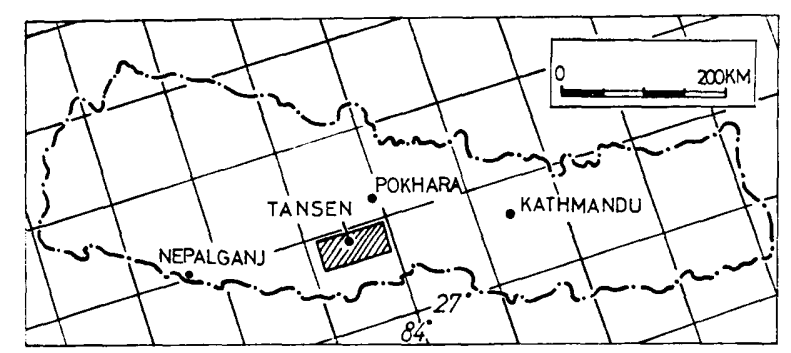

Fig. 1. Index map showing the location of the study area. 


\section{Geological Setting and General Geology}

The Himalayas in Nepal is geotectonically divided into the following four zones from north to south; the Tibetan Tethys, the Himalayan Gneiss, the Midland Metasediments, and the Siwaliks (Fig. 2). Physiographically the first two approximately belong to the Great Himalayas, the third to the Lesser Himalayas and the fourth to the sub-Himalayas. The Midland Metasediments zone of the Lesser Himalaya is bounded by the Main Central Thrust on the north and the Main Boundary Thrust on the south. In the tributary area of the Kali Gandaki river, it consists of very thick series of quartzite, pelitic schist and phyllite with some amphibolite, varicoloured slates, dolomite and limestone. It is in this southern part that the Nummulitic limestone and bivalves and gastropods-bearing shales are known to sporadically occur at several places (Hagen, 1969; Fuchs and Frank, 1970; Sharma, 1977).

The investigated area covers about 900 square kilometers in the southern border of the Lesser Himalayas, lies to the south of Riri Bazar in the middle reaches of the Kali Gandaki river and between the Purba river to the east and the Pindi river to the west, and includes the town of Tansen (Palpa) at a little north of the central area (Fig. 2). Altitude of this area ranges from 300 to $2000 \mathrm{~m}$.

The rocks of the Tansen area can be grouped into three divisions, the Kali Gandaki Group, the Tansen Group, and the Siwalik Group (Table 1, Fig. 3), the latter two being separated by the Main Boundary Thrust. The Kali Gandaki

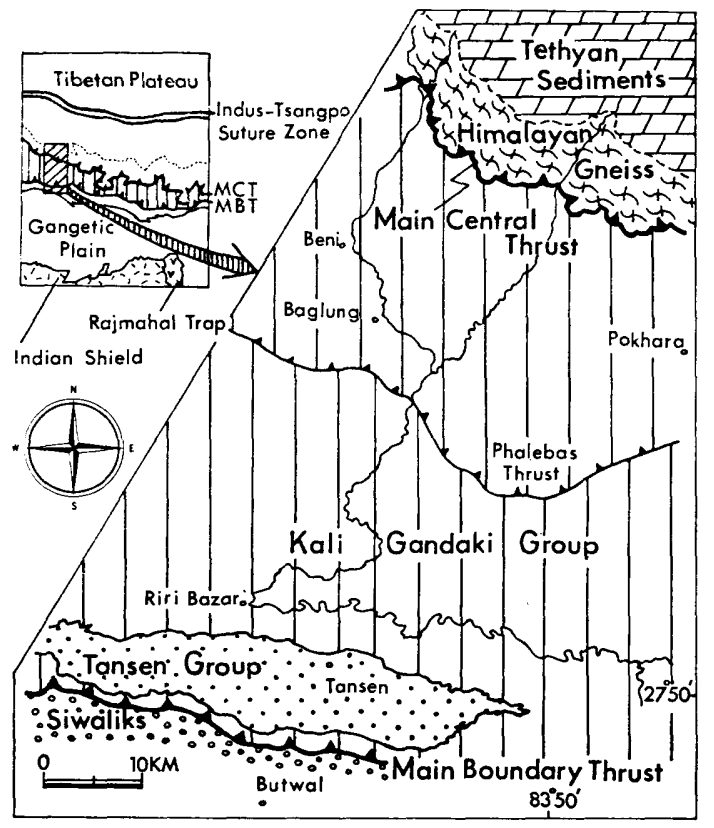

Fig. 2. Areal map showing the generalized geology of the western Central Nepal. 
Table 1. Summary of the stratigraphy and main lithology of rocks in the Tansen area.

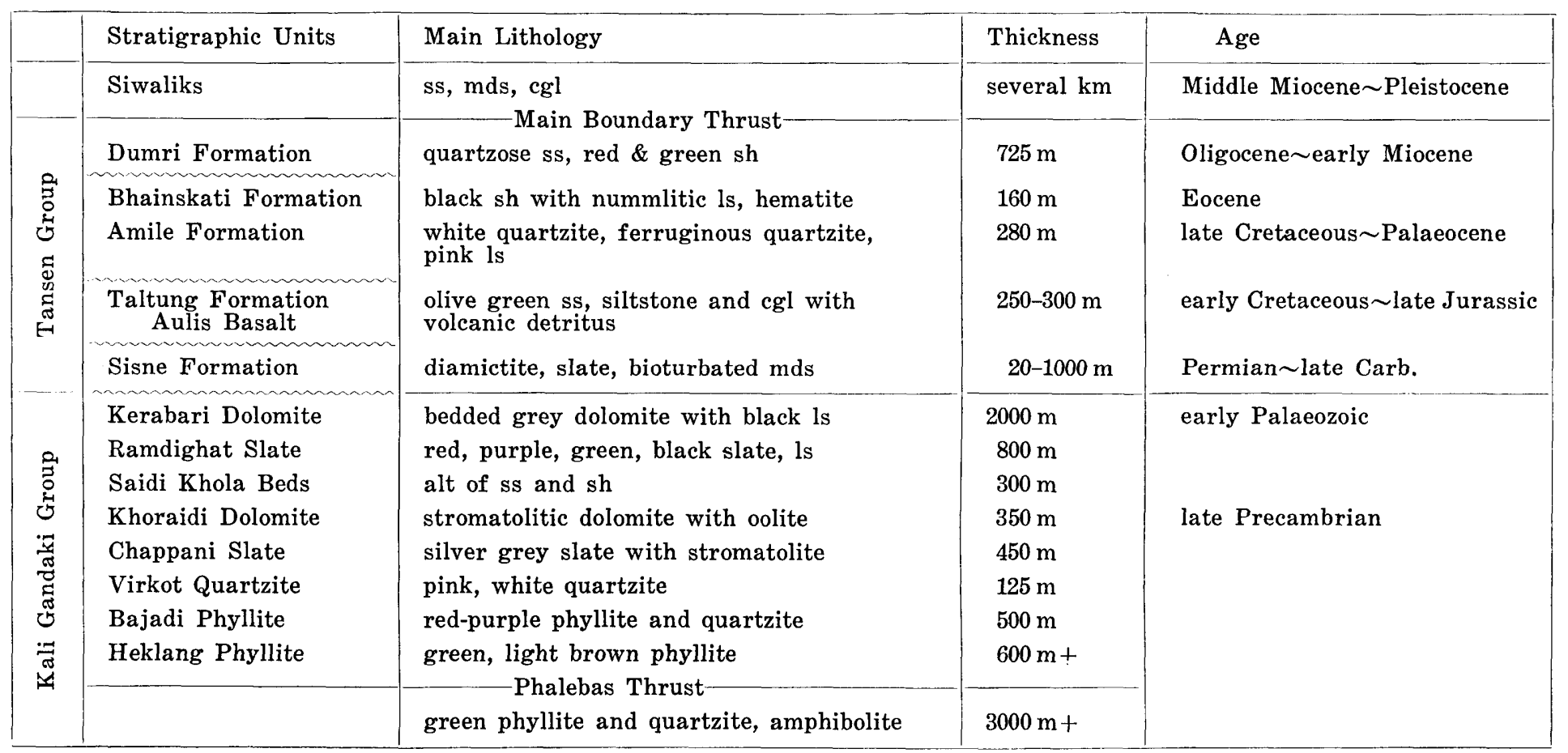




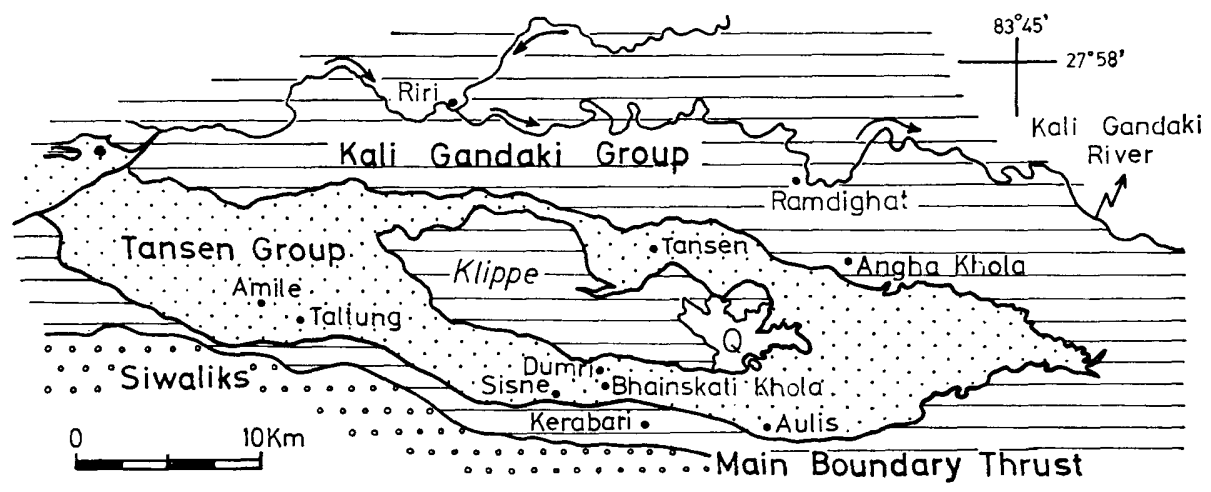

Fig. 3. Sketch-map of the geology of the study area. Large black dots with a place name indicate the type localities of formations of the Tansen Group.

is a thick sequence attaining $8000 \mathrm{~m}$ in tickness and consisting chiefly of quartzite and argillite in the lower, and carbonates, mostly dolomite, including stromatolite in the upper. The age of this group is unknown, but probably ranges from early Palaeozoic down to Precambrian. The Tansen Group is composed mostly of clastic rocks ranging from late Carboniferous to early Miocene. It is embraced in a trough-shaped, doubly plunging synclinorium, here named the Tansen Synclinorium, which is $57 \mathrm{~km}$ long in the eastwest direction and up to $10 \mathrm{~km}$ wide in the northsouth. The Tansen Synclinorium is all around tectonically bounded by the basal thrust which is represented by an upthrust on the southern front and a downslide at the rear on the north associated with the overthrust of the Kali Gandaki on the northeastern and northwestern sides. In the central part of the Synclinorium a large klippe of the Kali Gandaki Group thrust upon the Tansen Group with an intense rupture zone (Fig. 3).

\section{Stratigraphy}

\section{A. Tansen Group}

The Tansen Group is herein newly defined as the sequence mostly of clastic rocks embraced in the Tansen Synclinorium. It attains $2400 \mathrm{~m}$ at maximum thickness and is divided into the the following five formations (Fig. 4, Table 1); the Sisne Formation, mainly glacio-fluvial and glacio-lacustrine and marine sediments of late Carboniferous to Permian, Lower Gondwana age; the Taltung Formation, fluvial sediments of late Jurassic to Cretaceous, Upper Gondwana age; the Amile Formation, fluvio-deltaic sediments probably referable to the Cretaceous, the Bhainsksti Formation, shallow marine to brakish-water deposits of middle to late Eocene age; and the Dumri Formation, fluvial deposits of probably early Miocene age. At the base of the Sisne, the Taltung and the Dumri Formation a disconformity is present respectively. Basalt lava flows are intercalated in the basal part of the Taltung Formation. The Tansen Group within the synclinorium is in fault contact with the Kali Gandaki as stated 
1. red-purple shale; 2. green shale; 3 . black shale and slate; 4. silty sandstone; 5 . sandstone; 6. pseudo-conglomerate; 7 . conglomerate; 8. diamictite; 9 . bioturbated mudstone; 10. limestone; 11. hematite; 12. Aulis Basalt; 13. animal fossils; 14 . plant fossils; 15 . unconformity. 16. fault

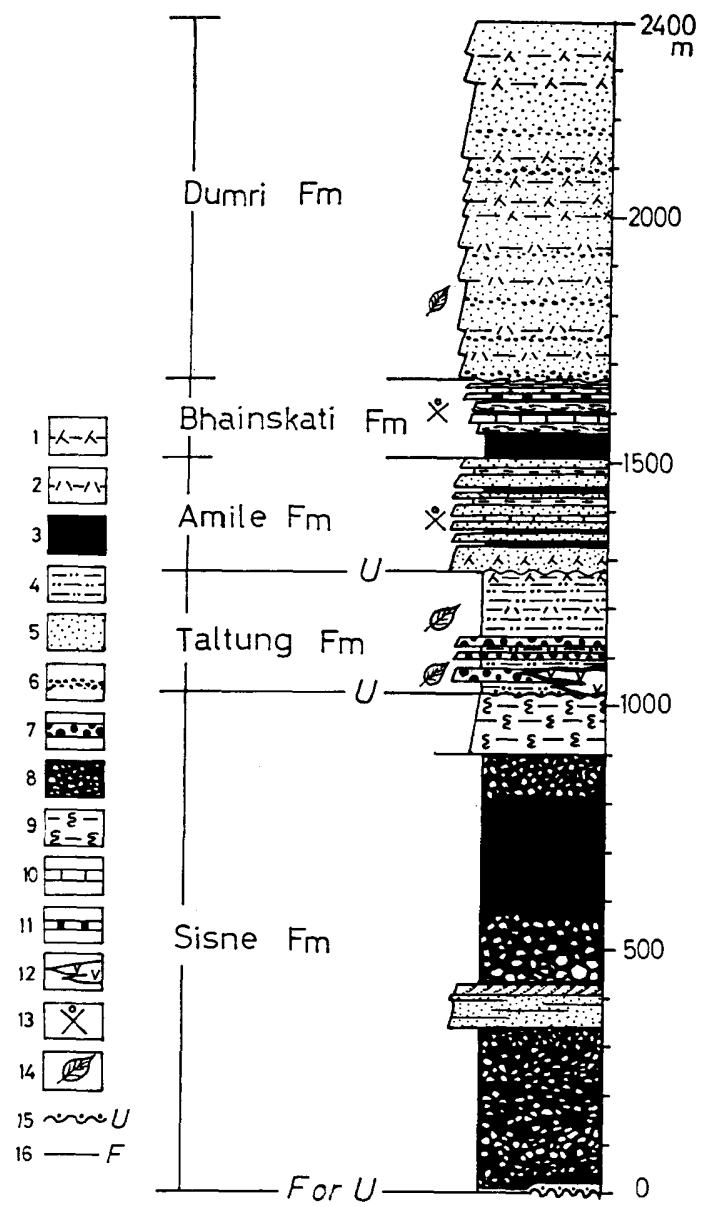

Fig. 4. Generalized lithostratigraphic section of the Tansen Group.

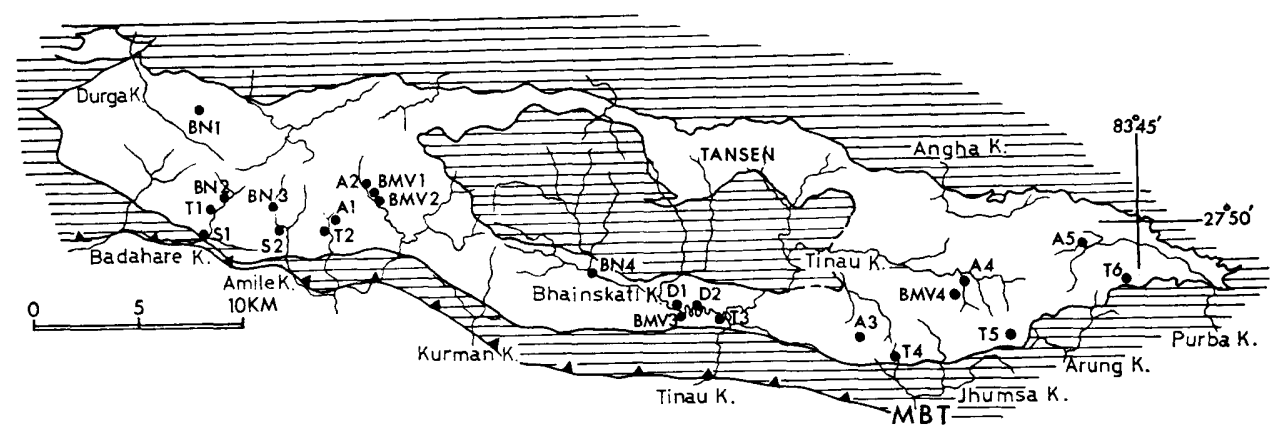

Fig. 5. Map showing fossil localities of the Tansen Group. S, bryozoan fossils from the Sisne Formation; T, Upper Gondwana plant fissil from the Taltung Formation; A, fossils from the Amile Formation; BN, larger foraminiferas from the Bhainskati Formation; BMV, molluscan and vertebrate fossils from the Bhainskati Formation; D, fossils from the Dumri Formation. 
Table 2. List of fossils newly discovered from the Tansen Group

\begin{tabular}{|c|}
\hline Dumri Formation-- - - Oligocene early Miocene \\
\hline $\begin{array}{l}\text { Vertebrate bone fragments } \\
\text { Wood trunk and its fragments }\end{array}$ \\
\hline Bhainskati Formation- - - early ? late Eocene \\
\hline $\begin{array}{l}\text { Nummulites beaumonti d'Archaiac and Haim } \\
\text { Assilian papillata Nuttal } \\
\text { Asteracantus sp. } \\
\text { Land mammal (left radius, costa, vertebra) } \\
\text { Teleostei (vertebra, spine, skull) } \\
\text { Chelonia (carapace) } \\
\text { Trionichidae (carapace) }\end{array}$ \\
\hline Amile Formation- - - late Cretaceous $\sim$ Palaeocene \\
\hline $\begin{array}{l}\text { Screlactinean coral } \\
\text { Shark teeth } \\
\text { Vertebrate bone fragments } \\
\text { Gastropods } \\
\text { Pelecypods } \\
\text { Echinoids }\end{array}$ \\
\hline Taltung Formation $--\ldots$ - -late Jurassic $\sim$ early Cretaceous \\
\hline $\begin{array}{l}\text { Ptilophyllum sp. } \\
\text { Pterophyllum sp. } \\
\text { Cladophlebis sp. } \\
\text { Elatocladus sp. } \\
\text { Pteridospermae }\end{array}$ \\
\hline Sisne Formation- - - Carboniferous Permian \\
\hline $\begin{array}{l}\text { Fenestella sp. } \\
\text { Polypora sp. } \\
\text { Acanthocladia sp. }\end{array}$ \\
\hline
\end{tabular}

above, but the base of the group was confirmed to rest disconformably on the Kali Gandaki in the Besarka Outliers which lies in the upper stream of the Arung river on the outside of the synclinorium (Fig. 23). The upper limit of the group is placed at the exposed top of the Dumri Formation.

\section{Sisne Formation}

Type locality: From Sisne Gaon to Patan along the upper stream of the Sisne river

Thickness: $1020 \mathrm{~m}$ at maximum

\section{a. Distribution and Stratigraphy}

The Sisne Formation that occupies the lowest part of the Tansen Group is extensively distributed along the outer margin of the Tansen Synclinorium (Fig. 23). Its apparent thickness varies in places owing to the structural repetition or the truncation by thrust faults. 
The base of the Sisne Formation cannot be defined within the Tansen Synclinorium because of the fault relation of the formation with the Kali Gandaki Group. However, on the southeastern side of the Tansen Synclinorium are two small outliers of this formation near the village of Besarka along the upper reaches of the Arung river (Fig. 23), where the Sisne Formation rests disconformably on the Kerabari Formation of the Kali Gandaki Group with a basal conglomerate as shown in Fig. 6. The basal conglomarate is $20 \mathrm{~cm}$ thick, and cosists of angular pebbles and cobbles of algal, oolitic and massive dolomite and chert (Pl. 4-Fig. a), whose lithologies suggest their derivation from the underlying Kerabari Formation. The top of the coglomerate is pigmented reddish and is covered by a film of limonite.

The basal conglomerate is followed successively by a $50 \mathrm{~cm}$ micaceous shale with plant remains, a 4 to $5 \mathrm{~m}$ black massive claystone and a $6 \mathrm{~m}$ unsorted mudstone containing sands and granules of various kinds (Fig. 6). The last bed lies on an uneven surface, tends to contain larger clasts at up-sections and represents a fine-grained facies of diamictite. This bed is covered by the basal volcanic conglomerate of the Taltung Formation with a distinct erosion surface.

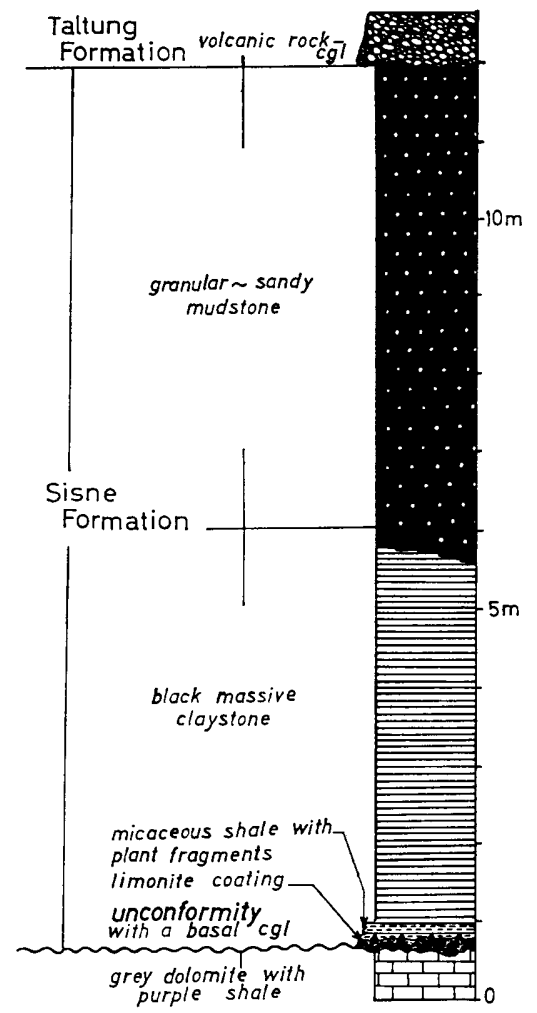

Fig. 6. Lithostratigraphic section of the basal member of the Sisne Formation in the Besarka Outliers, where the unconformable relation between the Sisne Formation and the underlying Kali Gandaki Group can be seen. 
Thus the Sisne Formation of the Besarka Outliers represents only the basal member of the formation.

The Sisne Formation of the Tansen Synclinorium consists mainly of diamictite and claystone or mudstone (largely converted into slate) with some beds of sandstone and conglomerate. The formation is faulted by a basal thrust and often repeated by folding, and also shows remarkable lateral and vertical changes of lithologies. In addition, as no marker beds are present and bedding features are uncommon, determination of the attitude and thickness are known only approximately. Therefore, the designation of the type section is a matter of difficulty. But the exposures along the Sisne river appears to provide the most complete section of the Sisne Formation (Fig. 7), because neither structural repitition nor truncation of beds were recognized there, although its lower limit cannot be defined owing to the Tansen Synclinorium boundary fault mentioned before.

The lowermost bed exposed in the type area is black slate up to $10 \mathrm{~m}$ thick. Its upper part contains clasts of a sand to granule-size and grades upward into the overlying diamictite beds containing larger and more abundant clasts. This bed is very similar in lithology and lithologic sequence to the black mudstone of the basal member of the Sisne Formation in the Besarka Outliers stated above, and is thought to be equivalent in the stratigraphic position to the latter.

The Sisne Formation in the type area consists of a thick sequence of diamictite attaining more than $300 \mathrm{~m}$ in the lower part, and is followed by sandstone about $80 \mathrm{~m}$ thick and again by diamictite up to $80 \mathrm{~m}$ thick. The upper part is dominantly black shale and is accompanied with some beds of diamictite, and the $100 \mathrm{~m}$ thick alternating beds of mudstone and sandstone at the top is intensely bioturbated (Fig. 7).

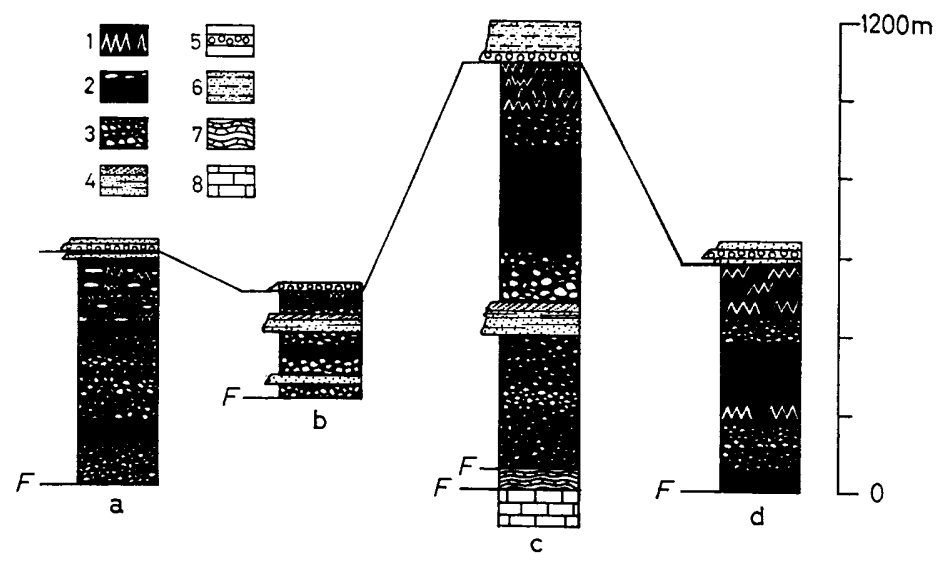

Fig. 7. Comparative lithostratigraphic sections of the Sisne Formation along a) the Badahare, b) the Kurman, c) the Sisne, and D) the Purba river. 1, bioturbated mudstone; 2 , calcareous concretions; 3 , diamictite; 4 , sandstone; 5 , conglomerate; 6 , silty sandstone; 7 , thin bedded shale with dolomite bands; 8 , Kerabari Dolomite. 7 and 8 belong to the Kali Gandaki Group. 


\section{b. Lithology}

Diamictite of the Sisne Formation shows wide variations in the proportion of the contained clasts to the interstitial matrix. Most dominant is the type that is completely unstratified, and is comprised of a structureless clayey matrix containing scattered clasts of considerably different sizes and shapes as shown in Figs. a, \& b, Pl. 3. Diamictite that has a sandy to silty clay matrix is also common (Pl. 1, Fig. a), and the ratio of contained clasts to the matrix varies considerably, for example between several pieces $/ \mathrm{m}^{2}$ and 500 pieces $/ \mathrm{m}^{2}$. Sandy diamictite is occasionally found. It assumes a greenish-gray colour and is poorly bedded and sorted, so when the contained clasts are abundant, it may be called conglomerate rather than called diamictite. Sandy diamictite is found commonly in the lowest part of the lower diamictite beds, that is, along the extreme margin of the Tansen Synclinorium.

The majority of the clasts are granites, gneissose rocks, limestone, dolomite and sandstone. Slate and phyllite are less common, and volcanic rocks are rare. These clasts generally range from a sand- to boulder-size, but rarely exceed $2 \mathrm{~m}$ across (Pl 3, Fig. c). Those larger than $1 \mathrm{~m}$ across are mostly granites and gneisses. The diamictite beds just above the sandstone beds in the middle part of the Sisne Formation contain large boulders (Fig. 7). Roundness of the clasts ranges from angular to well-rounded, but angular to subangular clasts attain more than $50 \%$. The clasts often show facet surfaces, but no scratched striae on the clast surfaces has been found. An interesting example regarding the occurrence of clasts was seen in some exposures, where large granite-boulders are accompanied on their lower corners by a $20-30 \mathrm{~cm}$ long trail consisting of rip-off fragments of those granites.

Claystone forms a major constituent of the Sisne Formation. It is darkgrey to black, and massive, although incipient lighter-coloured banding or lamination one to several centimeter thick is observable when the rock surfaces are polished and wet. This banding is owing to slight differences of size and contents of sand grains. Occasionally thin, elongate calcareous concretions, $2 \mathrm{~m}$ long and $20 \mathrm{~cm}$ thick at maximum, are present. Besides these, no other clues to determine the attitude of claystones were found. Slaty cleavages arranged oblique to the bedding planes are more or less strongly developed in claystones, clayey matricies of diamictites. On weathering these claystones split into pencil-like or prismatic fragments along the cleavages. This weathering product resembles 'needle-shape' shales of the Talchir Series (KRIshnaN, 1982) in the Peninsular India.

Only a few beds of sandstone occur in the Sisne Formation. Most prominent is that of the middle part in the Sisne section. It is pale-green, thick-bedded and fine- to medium-grained. It is massive in the main part, but exhibits parallel and climbing ripple laminations in the upper part. Its main constituents are quartz, feldspars, and fragments of metamorphic and plutonic rocks. Well-preserved grains of perthite and microcline and mica flakes are also common. This sandstone is cemented with sparry calcite.

The uppermost part of the Sisne Formation, about $130 \mathrm{~m}$ thick in the type section, consists mainly of mudstone with rhythmically interlayered fine-grained 
sandstone at a few $\mathrm{mm}$ to a few $\mathrm{cm}$ interval. Several, 2 to $5 \mathrm{~m}$ thick, lenticular beds of diamictite are intercalated in the lower part. The sandstone beds show wavy to lenticular, in part flaser bedding usually as much as a few to $10 \mathrm{~cm}$ thick, rarely attaining $30 \mathrm{~cm}$. They assume a brown colour on weathering due to calcareous cement.

A notable feature of these uppermost beds is the strong bioturbation of varied patterns, which are represented by sinuous to nearly straight, vertically-, obliquely- and horizontally-oriented tubules or grooves, up to $2 \mathrm{~cm}$ across, interpreted to have been formed mainly by burrowing organisms (Pl. 3, Fig. d). The bedding surfaces are much destroyed, and mottled structures are very common at many horizons. As these strongly bioturbated beds are typically exposed between Ritung and Patan in the upper reaches of the Sisne river, I propose to name these beds the Ritung Bioturbated Mudstone. These beds can be traced almost all over the extention of the Sisne Formation except for the western corner of the Tansen Synclinorium, where the uppermost part of the Sisne Formation is represented by alternating beds of 5 to $10 \mathrm{~m}$ thick sandstone and shale. Even in these beds, bioturbation was commonly observed.

Several mudstone floats containing abundant Fenestella were discovered within the area of the Sisne Formation. These are thought to have been derived from the Ritung Bioturbated Mudstone, because of their close lithologic similarlities.

\section{c. Provenance of diamictite clasts and origin of the Sisne Formation:}

Most abundant and large clasts contained in diamictites of the Sisne Formation are granites and gneisses, of which very prominent is pinkish to reddishbrown granite whose colour is originated from pinkish orthoclase and biotite. Porphyritic granite and gneiss, both containing pinkish or creamy white orthoclase phenocrysts or porphyroclasts, are also important components. These phenocrysts and porphyroclasts show a distinct lineation. Pinkish coloured gneiss with biotite and muscovite bands was commonly found. These granites and gneisses form a characteristic rock association in having a pinkish feldspar and similar in lithic character to the Malani Granite and associated rocks

\section{Explanation of Plate 3}

Fig. a: Sisne Diamictite. Angular pebble-sized clast of carbonate rocks are scattered in structureless, claystone matrix. Gobli Khola.

b: Sisne Diamictite with a well-rounded cobble and angular pebbles of biotite granite in weakly cleaved claystone. Angular sands and granules of granite origin are also disseminated. near Amile.

c: A big, faceted boulder of gneissose porphyritic granite, washed out from the Sisne Diamictite. Lamachaur Khola.

d: Ritung Bioturbated Mudstone in the upper part of the Sisne Formation. Sandy layers are vermiculated by the churning action of organisms. This bed is interpreted as a nearshore marine deposit. Sisne Khola. 

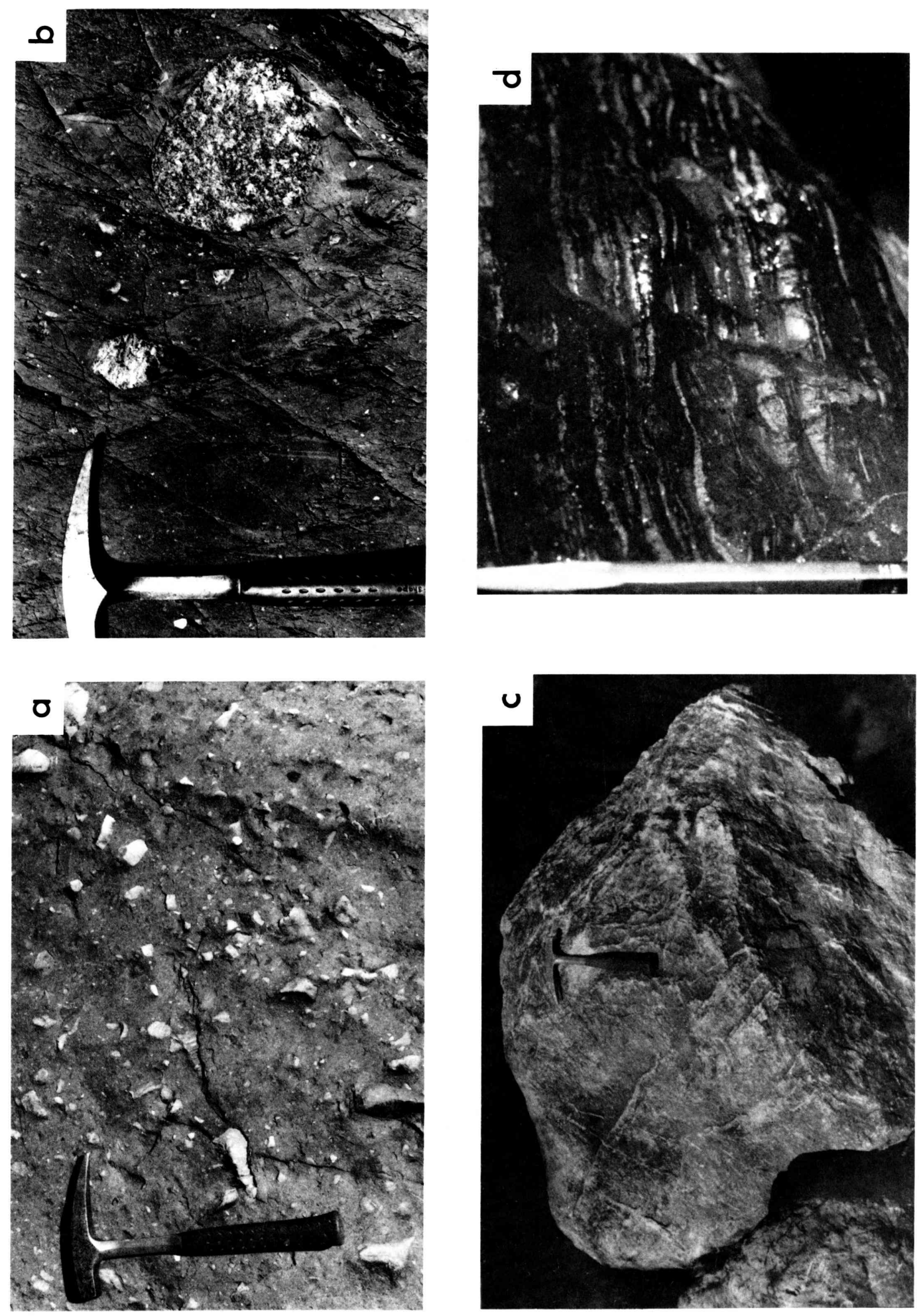

H. SakaI: Geology of the Tansen Group 
Mem. Fac. Sci., Kyushu Univ., Ser. D, Vol. XXV

Plate 4
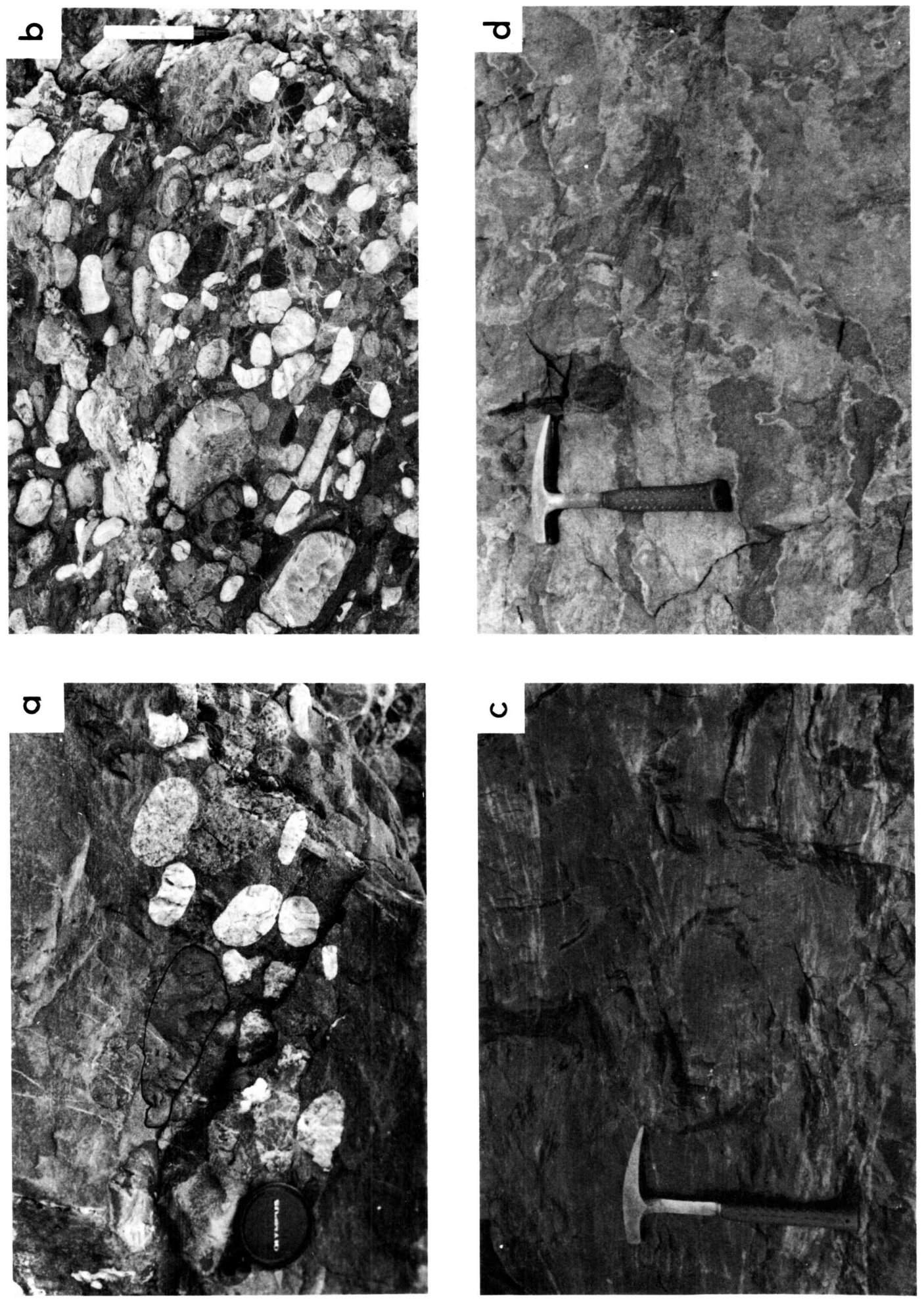

H. SAKaI: Geology of the Tansen Group 
(GANSSER, 1964) in the northern Indian Peninsula.

Clasts of limestone, dolomite, quartz arenite, and quartzose sandstone constitute another association of rocks which is just the same as that of the Kali Gandaki Group and its correlatives, the Vindyan System (GANSSER, 1964) of the north Indian Peninsula. Thus, most of the clasts of the Sisne Diamictite is thought to have been derived from the Malani Granite and the Vindyan System. This consideration is also supported by analysis of palaeo-current system deduced from cross-bedding of sandstones and imbrication structures of conglomeratic beds, both in the middle and upper part of the Sisne Formation. All the data obtained indicate current direction from southwest to northeast or from southeast to northwest.

No definite evidence indicating glacial origin of the Sisne diamictite such as scratched striae on pebble surfaces was found. However, the general sedimentary features represented by massive, unsorted deposits with an overwhelming clayey matrix that contains scattered clasts ranging from a sand to huge boulder-size suggest glacial origin. In addition, associated claystones indicate deposition in quiet water environment, and those exhibiting thin bands, although it is incipient, are attributable to varved shale. These claystones occassionally contain isolated clasts including huge boulders, which are probably referable to dropstone.

Thus, a large part of the Sisne diamictite seems to be glacial origin detritus. However, the poorly stratified diamctite with a sandy matrix in the lower part, $80 \mathrm{~m}$ thick sandstone beds in the middle part and the underlying alternating beds of thin conglomeratic layers with imbricated pebbles, sandstones exhibiting climbing ripple lamination and a distinct scour at the base, and the underlying claystone clearly indicate the deposition under the influence of water current, probably in a glacio-fluvial environment. On the other hand, the Ritung Bioturbated Mudstone in the uppermost part of the Sisne Formation seems to be shallow marine, probably tidal flat deposits by the rhythmic layering of sandy and muddy beds and the extensive bioturbation by burrowing organisms.

\section{d. Mode of Occurrence of Fossils, Age and Correlation}

Some floats of shale which abundantly contain fenestellan bryozoa were

\section{Explanation of Plate 4}

Fig. a: A thin conglomeratic layer of the Taltung Formation underlain by cross-laminated sandstone, and parallel laminated silty sandstone. The imbricated pebbles show a unimodal pattern of flow direction from E SE. Bhainskati Khola.

b: Imbrication of pebble is clear Charchare Conglomerate at the base of the Taltung Formation. This conglomerate is interpreted as riverstream laid deposits.

c: Pi-cross stratification (Allen, 1963) of the Amile quartzite. Purba Khola.

d: Quartzose sandstone mottled with ferruginous matter in the lower part of the Amile Formation. Upper stream of the Amile Khola. 
obtained near the boundary fault between the Kali Gandaki Group and the Tansen Group in the upper reaches of the Badahare river, where two tributaries are confluent as is shown in Fig. 5. In the upstream area the Tansen Group that begins with the Sisne Diamictite is widely distributed. The shale floats, one of which is as large as $1 \mathrm{~m}$ across, very much resemble calcareous sandy mudstone shale in the Ritung Bioturbated Mudstone Member in lithic characters and weathering features. It is thought, therefore, that the floats have been derived from the upper part of the Sisne Formation.

In the floats obtained, bryozoan fossils occur as thin bands or laminae full of zoaria, being interlayered with sandy mudstone bands. The bryozoan zoaria have been dissolved away and their external moulds are preserved. The contained bryozoa belong to the genera Fenestella, Polypora and Acanthocladia, but specific identification cannot be made because of their poor preservation. Besides these, a species composed of a branching colony is contained. The genera Fenestella and Polypora are known to range from Ordovician to Permian, but the obtained specimens have affinities to the species of Carboniferous and Permian ages. Acanthocladia is known to occur from the Carboniferous and Permian. Thus the bryozoan fossils in question are of Carboniferous to Permian age.

The Fenestella Shales which are well known to represent part of the Lower Gondwana of late Carboniferous or Carboniferous to Permian age are widespread in Salt Range, Lesser Himalayas of Kashmir and Garhwal (Ganestan, 1972) and Higher Himalayas of north Central Nepal (GANSSER, 1964 ; KrishinaN, 1982) and Arunachal Pradesh (JAIN \& DAs, 1973). However, regarding the stratigraphic relationship between the boulder beds with glacial influence and the Fenestella shales still remain uncertain. According to GANSSER (1964), in the Panjab Himalaya, some fossiliferous beds which have affinities to the Fenestella Shales are intercalated in the Agglomeratic Slate. On the other hand, late Palaeozoic fossils including Fenestella have not been reported from the Kumaon and Nepal Lesser Himalayas. This finding of floats of the Fenestella Shales would be a momentum that the stratigraphic relationship between the boulder beds and the Fenestella Shales could be confirmed in Nepal.

The Sisne Formation is characterized by thick beds of diamictite or boulder clay beds. In this respect, this formation is safely correlated as a whole with the lower part of the Lower Gondwana (KRISHNAN, 1982) or at least part of it, that is, the Tailchir Series in the Indian Peninsula, and the Agglomeratic Slate in Panjab and the Blaini Boulrder Beds in Kumaon, both in the Lesser Himalayas. These boulder beds or tillites have been referred to late Carboniferous or late Carboniferous to early Permian. Since the diamictite beds of th Sisne Formation occur at least three horizons and are much thicker as compared with the boulder beds mentioned, the Sisne Formation may probably range from late Carboniferous to early Permian.

\section{Taltung Formation}

Type locality: Upper stream of the Dobhan river near Taltung Thickness: about $200 \mathrm{~m}$ 


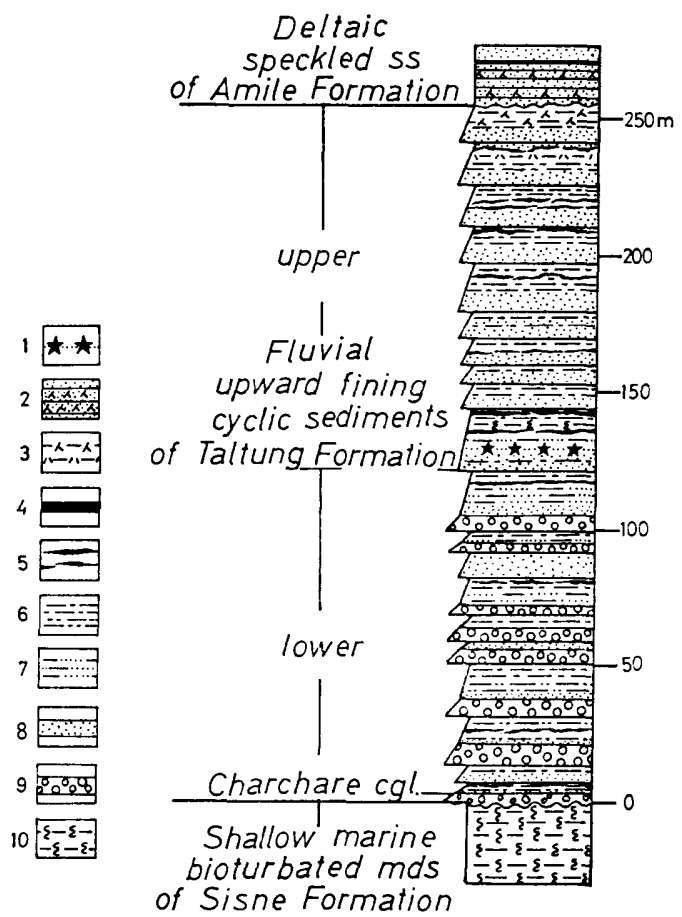

Fig. 8. Lithostratigraphic section of the Taltung Formation. 1, calcareous speckled siltstone; 2, quartzose arenite with ferruginous mottles; 3 , red-purple and green shale; 4 , black shale; 5 , carbonaceous shale; 6 , siltstone; 7 , silty sandstone; 8 , sandstone; 9 , conglomerate; 10 , bioturbated mudstone of the Sisne Formation.

The Taltung Formation disconformably rests on an eroded surface of the Sisne Formation, from which some thickness of sediments were removed and angular boulders of the Sisne diamictite and mudstone were transported into the overlying basal conglomerate of the Taltung Formation (Fig. 9). The Taltung Formation at the type locality is divided into two members; the Lower characterized by a cyclic sedimentation comprising conglomerate, sandstone and shale in ascending order; the Upper by a rhythmic alternation of sandstone and shale (Fig. 8). Thus, this formation is easily distinguished from the underlying Sisne Formation in having a different lithofacies. In addition, in the Aulis and Taltung areas in the southern tract of the Tansen Synclinorium, some basalt lava flows, named the Aulis Basalt, are intercalated near the base of the formation, and the beds of the Lower Member contain more or less considerable amounts of volcanic rock fragments and assume an olive-green colour.

\section{a. Charchare Conglomerate}

The basal conglomerate of the Taltung Formation forms an important 


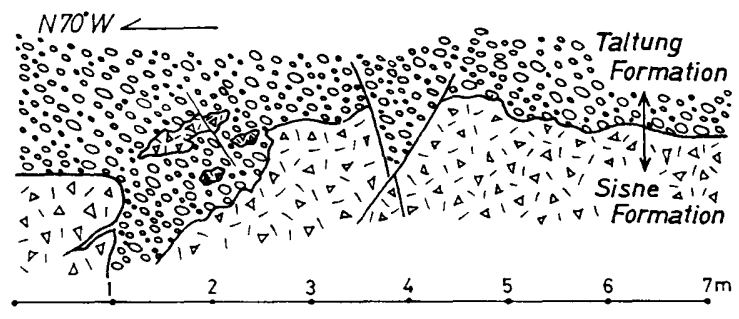

Fig. 9. Sketch of the disconformity of the Taltung Formation and the underlying Sisne Formation at the type locality of the Taltung Formation. Note the eroded surface on the Sisne diamictite and large, angular boulders of diamictite in the overlying conglomerate.
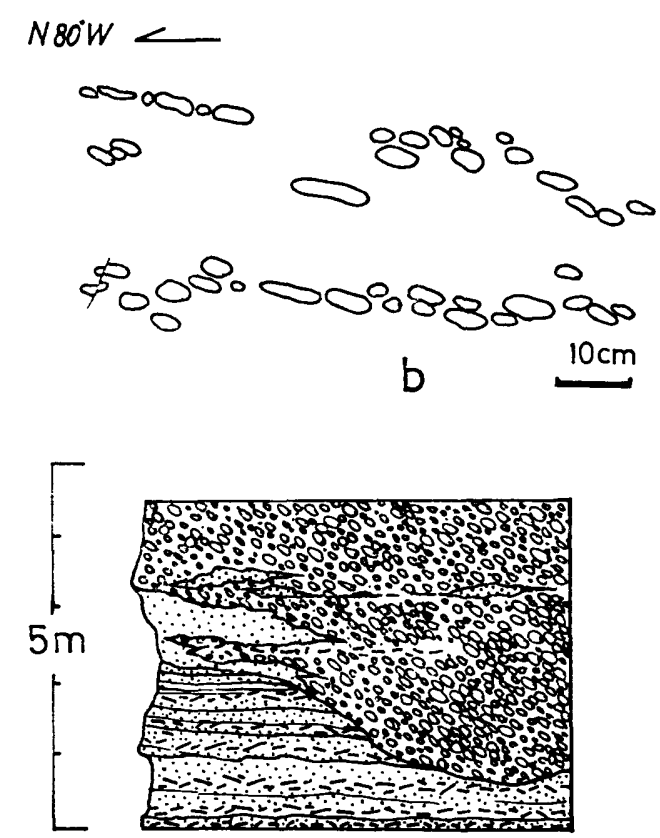

a

Fig. 10. a, Sketch of the Charchare Conglomerate infilled a remarkable scour on sandstone wedge beds at the basal part of the Taltung Formation and the intertongue relation of sandstone to conglomerate. Small bar symbol in the underlying standstones indicates plant fossils. b, Imbrication of pebbles of the Charchare conglomerate that shows the paleocurrent direction from east to west.

marker bed which is traceable throughout the extension of the formation in the study area. It is herein named the Charchare Conglomerate after a small village 
of Charchare along the Tinau river. This conglomerate is less than $20 \mathrm{~m}$ in thickness and is $13 \mathrm{~m}$ at the type locality on the river side of the Tinau river. Its base shows a conspicuous scour of the underlying coarse-grained sandstone beds. It is chiefly composed of conglomerate with subordinate intertongues of sandstone, and roughly exhibits two upward-fining sequences with alternating beds of coarse-grained sandstone and thin conglomerate at the top (Fig. 10). This sequence is especially distinct in the upper reaches of the Jhumsa river.

The main part of the Charchare Conglomerate is usually densely packed with well-sorted pebbles and cobbles. The contained pebbles at the type locality have a grain-size distribution as shown in Fig. 11, and more than $75 \%$ of them are well rounded to rounded. In the Purba river area the pebbles are dominantly of a cobble size, reaching a maximum diameter of $60 \mathrm{~cm}$. Sandstone tongues range in extension from a few tens of $\mathrm{cm}$ to $10 \mathrm{~m}$ or so, and rapidly thicken and thin out laterally. They often contain isolated pebbles or thin, poorly sorted pebble layers which are seen as linear stripes of pebbles in cross-section (Fig. 10b). Strongly flattened wood fragments are also common in the sandstone tongues. In the Purba river area the uppermost part of the Charchare Conglomerate comprises cross-bedded coarse-grained sandstone and pebble to cobble layers interbedded at intervals of a few tens of cm (Fig. 12).

One of the important features of the Charchare Conglomerate is a unique composition of pebbles; it consists only of two rock types, igneous rocks mainly of volcanic rocks and quartzite. Most abundant is basalt which was evidently derived from the Aulis Basalt. There are also some dolerite and gabbro which are thought to be syngenetic with the Aulis Basalt from their lithologic character. Basalt pebbles are varied between aphanitic basalt to porphyritic basalt. Many of them are amygdaloidal basalt whose vesicles are filled with either calcite and chlorite or chalcedony and chlorite. Quartzose arenite pebbles are well rounded. Some of them contain a small amount of flakes of green chlorite and muscovite. Pebbles of black slate and granites were rarely found. The matrix of conglomerates comprises angular to subrounded, coarse-grained sand of basaltic rocks and qartzite, and assume an olive-green colour. It is the same in composition and colour as the inerbedded and overlying sandstones.

In the sequence of the Charchare Conglomerate the composition of pebbles varies fairly markedly. At the type locality quartzite forms about $40 \%$ of the conglomerate in the lower part, but it decreases to $15 \%$ in the upper, whereas volcanic rocks attain $85 \%$. In the Purba river area monomictic conglomerates consisting almost entirely either of well-rounded quartzite pebbles or poorly sorted and subangular pebbles and cobbles of porphyritic basalt were recognized. In the upper stream of the Badahare river, well-sorted boulder conglomerate comprised almost exclusively of porphyritic basalt is present above the Aulis Basalt.

Another notable feature of the Charchare Conglomerate is imbrication of pebbles. In the main part of the conglomerate pebbles are imbricated one another with direct contact (Pl. 4, Fig. a, Fig. 10b). Pebbles in the conglomerate layers within sandstones of the upper part also show a distinct imbrication, and laminae of the overlying sandstone abut against protruded surface of 


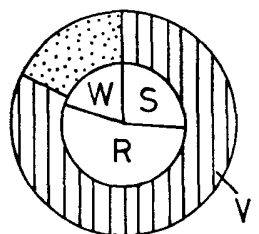

$n=50$

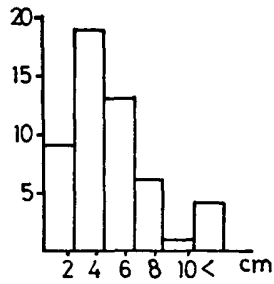

a

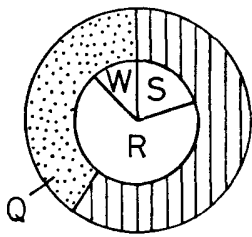

$n=50$

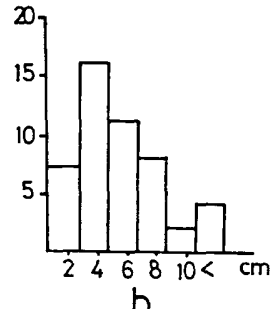

Fig. 11. Diagrams showing the composition and size frequency distribution of the Charchare Conglomerate at Charchare. a, upper part; b, lower part. V, volcanic pebbles; $Q$, quartzite pebbles; W, well-rounded; $R$, rounded; S, subrounded.

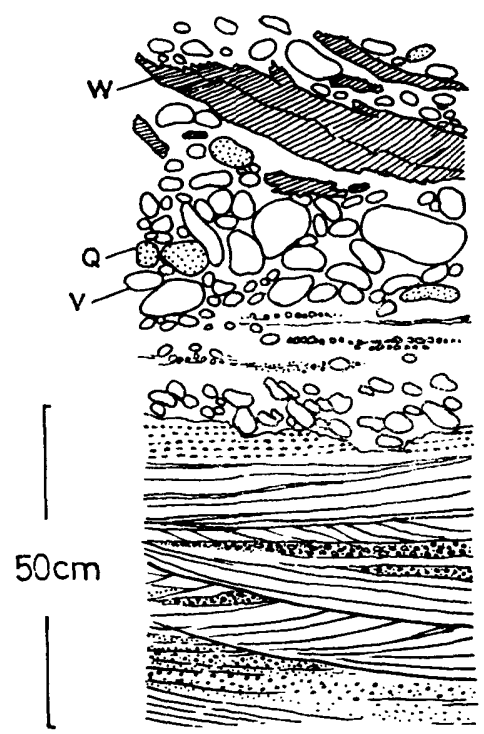

Fig. 12. Sketch of the cross-bedded sandstone and conglomerate of the Charchare Conglomerate. Note imbrication of pebbles and wood fragments. W, fossil wood; Q, quartzite pebbles; V, volcanic rock pebbles.

pebbles at a large angle as seen in Pl. 4, Fig. a. A preferred orientation and imbrication of pebbles indicate a current direction from SE to NW in the larger part of the study area. Silicified or calcified wood fragments up to a length of $1 \mathrm{~m}$ were sometimes found in conglomerate. They also show imbrication with 


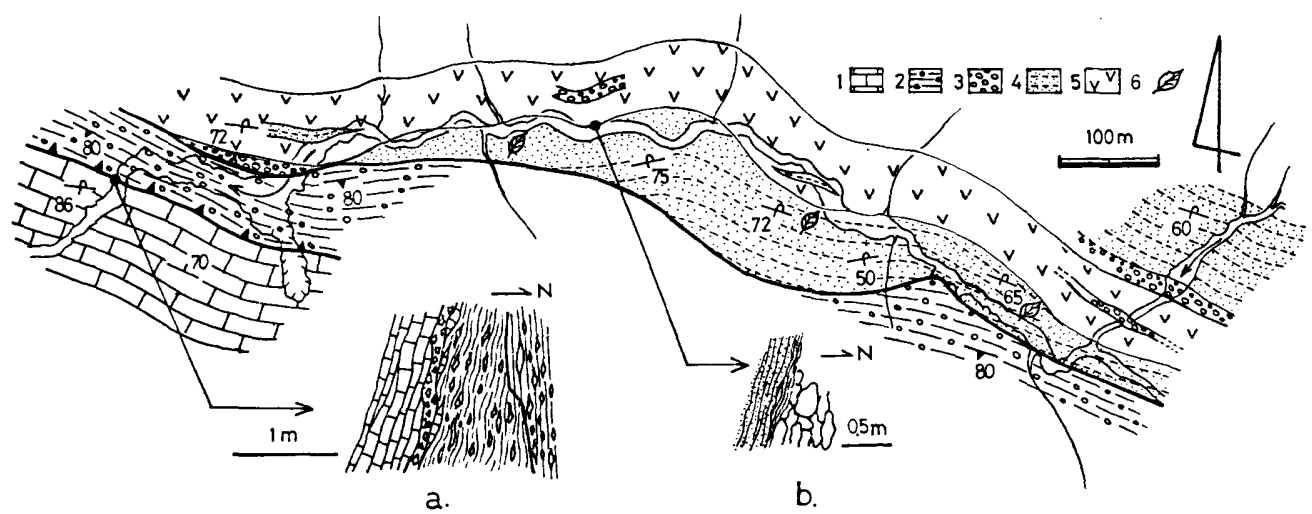

Fig. 13. Geological map along the upper reaches of the Tinau river, south of Aulis, showing the mode of occurrence of the Aulis Basalt and the Taltung Formation. a, fault contact between the Kerabari Dolomite and the Sisne Diamictite; b, pillow structure at the basal part of the Aulis Basalt. 1, Kerabari Dolomite; 2, Sisne Diamictite; 3, Conglomerate; 4, silty sandstone of the Taltung Formation: 5 , Aulis Basalt; 6 , locality of plant fossils.

the same direction as pebbles (Fig. 12).

\section{b. Aulist Basalt}

Type locality: Along a tributary of the Tinau river, south of Aulis Thickness: 20 to $200 \mathrm{~m}$

Basaltic lave flows, herein named the Aulis Basalt, are associated with the Lower Member of the Taltung Formation in the Aulis, Badahare and Amja areas in the southern flank of the Tansen Synclinorium. Smaller ones were also found in the upper reaches of the Durga river in the northwestern corner of the synclinorium (Fig. 23). Altogether, three lava flows were recognized; one occurs directly on the Charchare Conglomerate distributed along the Badahare river, and the others were found in a slightly higher levels, that is, in the lower part of the Lower Member. Besides these, it is deduced from the existnce of lots of basalt pebbles in the Charchare Conglomerate that basalt extrusives were also present simultaneously with or prior to the sedimentation of the Charchare Conglomerate.

All the basalt lava flows occur parallel to subparallel with the stratification planes of the Taltung Formation, and usually have one or two intercalations of sandstone or conglomerate which comprises clasts of only basalt and quartzite. Prominent among these lavas occurs in the Aulis area and is well exposed along a tributary of the Tinau river and along the Jhumsa river. It is 30 to $200 \mathrm{~m}$ thick and extends over $13 \mathrm{~km}$. In the south of Aulis, two flows were recognized (Fig. 13), whereas in the Jhumsa river area three flows are present (Fig. 14). Those in the upper stream of the Amile and the Badahare river extends $7 \mathrm{~km}$ and are generally 40 to $50 \mathrm{~m}$ thick, attaining a maximum thickness of $100 \mathrm{~m}$ including at least two clastic intercalations. In some places where the basalt flows thin to a few meters, they are overlain by thick beds of monomictic con- 


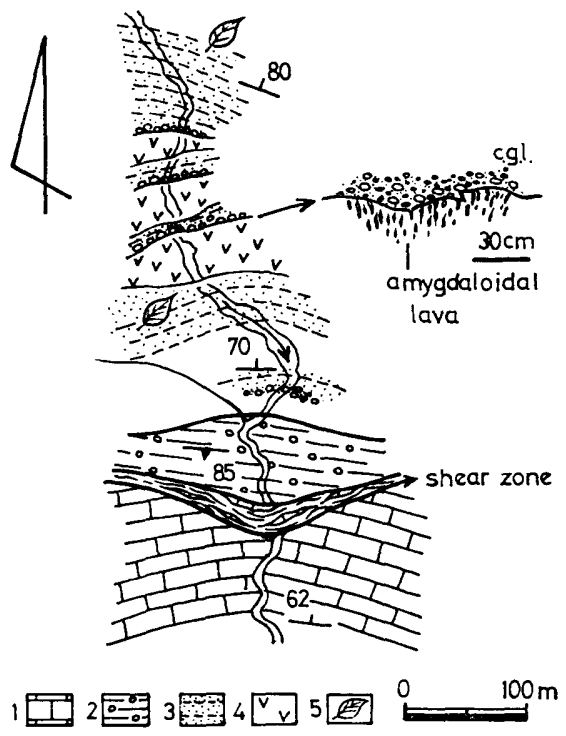

Fig. 14. Sketch map along the upper stream of the Jhumsa river, showing the mode of occurrence of three flow units of the Aulis Basalt with conglomerate interbeds. 1, Kerabari Dolomite; 2, Sisne Diamictite; 3 , silty sandstone of the Taltung Formation; 4 , Aulis Basalt 5, locality of plant fossils.

glomerate consisting only of pebbles, cobbles and boulders of basalt which has the same lithologic character as the underlying basalt. The total thickness of the basalt flows and the volcanic conglomerate is nearly equal to an average thickness of lava flows in the same area. In the Durga river area two flows attaining more than $40 \mathrm{~m}$ thick were recognized.

The basalt lava flows are dark-green to dark-grey, generally massive, but are pillowed in part, particularly in the lower and upper margins (Fig. 13). The upper part of pillows is often amygdaloidal with cylindrical vesicles which attain as large as $2 \mathrm{~cm}$ in diameter and $6 \mathrm{~cm}$ in length. The vesicles are arranged nearly perpendicular to the pillow surfaces. Sometimes subspherical amygdales are present even in the middle part of lavas.

All the basalt flows have the same lithologic character. The rocks are sparsely porphyritic having plagioclase phenocrysts scattered throughout an intersertal groundmass of lath-shaped plagioclase microlites and granular clinopyroxene. Plagioclase phenocrysts range in length from 0.2 to $0.8 \mathrm{~cm}$, whereas plagioclase microlites are less than $0.2 \mathrm{~mm}$ in length. The former has been largely altered to saussurite, whereas the latter partially altered. Most of clinopyroxene has been replaced by chlorite, but only some relicts are identified with clinopyroxene.

The Aulis Basalt is referable to the Upper Gondwana age, because plant fossils of that age were discovered from a level $7 \mathrm{~m}$ above the base of the Taltung Formation. This is the first report on the volcanic activity of the Upper Gondwana age from the Himalayan Range. 


\section{c. Lower Member}

The Lower Member of the Taltung Formation is characterized by upwardfining sequence, each beginning with conglomerate, continuing with sandstone and ending with silty shale (Fig. 8). Each cyclic unit ranges in thickness from 7 to $20 \mathrm{~m}$, and its base is usually marked by conglomerate fillings in scour channels cut into the underlying beds. In the type area at least eight conglomerate beds including the Charchare Conglomerate were recognized, but only a few conglomerate beds are exposed in the Sisne and Amja areas where part of the Lower Member is truncated by a thrust.

The conglomerate beds vary in thickness between 3 to $15 \mathrm{~m}$ except that $55 \mathrm{~m}$ thick in the upper stream of the Badahare river. They are almost the same as the Charchare Conglomerate in composition and other features, and also in the nature of the matrix. The conglomerate grades upward into coarse- to very coarse-grained sandstone, which in turn often exhibits large-scale trough-shaped or tabular to wedge-shaped cross-bedding in the lower and planar lamination in the upper. The top bed of each cyclic unit consists of finely laminated sandy siltstone or structureless greyish-green mudstone up to $8 \mathrm{~m}$ thick, and many carbonaceous seams.

In the type area, more than 8 beds of tuff, tuffaceous shale and sandstone are intercalated in the lowest part. Calcareous concretions ranging in size from 0.5 to $1 \mathrm{~m}$ are present in the sandstone beds.

Plant fossils referable to the Upper Gondwana Flora were abundantly found from several siltstone beds and also from thin silty layers within conglomerates in the lower part. In a tributary of the upper reaches of the Arung river, silicified trunks up to $40 \mathrm{~cm}$ in diameter and $60 \mathrm{~cm}$ in length were found from a coglomerate of the lower part.

The Lower Member is referable as a whole to fluvial sediments; the conglomerates which show a scour and fill structure indicate a probably abraided river channel deposits, the overlying cross-bedded sandstones are compared with the point bar deposits, and the siltstones at the top are ascribed to the overbank flood plain deposits.

\section{d. Upper Member}

The Upper Member of the Taltung Formation conformably follows the Lower Member and is characterized by upward-fining rhythmic sequences represented by alternating beds of sand and shale. Each rhythm ranges in thickness from 8 to $20 \mathrm{~m}$ (Fig. 8) Sandstone is olive-green in colour and very coarse- to medium-grained, and has the same lithologic characters as that of the Lower Member. The sandstone beds are usually massive, but some of them show a scour-and-fill structure at the base, are cross-bedded and contain many carbonaceous seams.

Sandstone beds grade upwargd into silty sandstone or sandy siltstone beds, which in turn to carbonaceous siltstone or shale beds. In the siltstone beds hematitic speckles and small calcareous concretions are common. The carbonaceous beds are indistinctly mottled by bioturbation. In some sandstone beds 
pyrite spherules 0.2 to $3 \mathrm{~cm}$ in diameter are scattered and the contained fossil wood fragments are also replaced by pyrite.

The uppermost part of the Upper Member consists of a 7 to $8 \mathrm{~m}$ thick, reddish-purple silty shale with greenish, irregularly mottled reduction spots.

The lithologic sequence of the Upper Member clearly indicate nonmarine origin and is referable to fluvial sediments as the Lower Member.

\section{e. Mode of Occurrence of Fossils, Age and Correlation}

The Taltung Formation, especially its lower half, yields abundant plant fossils at many horizons. Good exposures of plant beds are seen along the Bhainskati river around Charchare and the upper stream of the Amile around the Taltung and Betani. Plant fossils occur most commonly from siltstone beds, and less commonly even silty partings in coarse-grained sandstone and conglomerate beds. Best preserved were obtained from silicified siltstone and very fine-grained sandstone. The rocks of this area are so strongly jointed at short intervals as much as $10 \mathrm{~cm}$ that it is difficult to collect complete specimens. In many of fossil beds the plant remains are overlapped one upon another and show little post-withering damage. These features suggest in-situ accumulation in quiet water environment. The Taltaung plant fossils are of the first finding of the Upper Gondwana Plant in the Lesser Himalayan Range.

Most of the plant fossils obtained are the Bennettitales and Filicales. Four

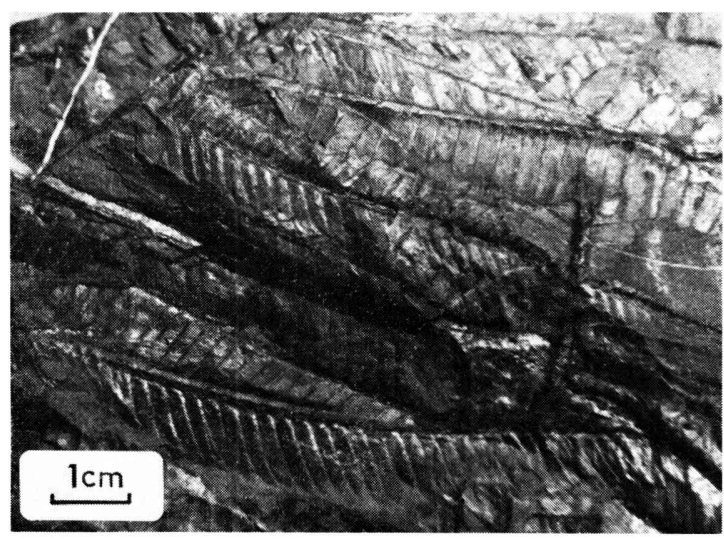

Fig. 15. Ptillophyllum sp. from siltstone of the Taltung Formation at Taltung (Fig. 18, T2).

genera belonging to Ptillophyllum, Pterophyllum, Cladophrebis and Elatocladus were found. The former two occurred from the lower part of this formation. Some specimens of the Pteridospermae were also found. Specific identification of these specimens has not yet been completed, but the floral assemblage of the genera mentioned is compared with that of the Upper Gondwana Plants of late Jurassic to early Cretaceous age which are well known in the Rajmahal and Jabalpur Series in the Indian Peninsula. Thus, the Taltung Formation is as- 
signed to that age, and the disconformity between the Taltung Formation and the underlying Sisne Formation implies a large time gap ranging at least from Triassic to early Jurassic.

The Taltung Formation is unique in sedimentary facies and contained fossil contents as compared with the Jurassic and Cretaceous rocks not only of other areas of the Lesser Himalayas but also of the Higher Himalayas, where the rocks of those ages are represented mostly by marine deposits containing abundant ammonoid and bivalve shells, although those of the Kumaon seem to include some nonmarine beds (GANSSER, 1964).

Of special interest is that the Taltung is accompanied by basaltic lavas, newly named the Aulis Basalt, in its lowest part. Nowhere in the Himalayan Range Jurassic volcanic activity has been known, but what may be related to this volcanic activity is volcanic pebbles of the ferruginous conglomerates in the Thakkhola region of the Tibetan Himalaya, northern Nepal (BoRDET, 1961). This conglomerates are associated with sandstones containing plant remains, lignites and silicified wood fragments, and underlies glauconitic sandstones leading into the Upper Jurassic Spiti Shales (BORDET, 1961). On the other hand, the Aulis Basalt is safely correlated with the Rajmahal Traps of the eastern Peninsula shield north of Calcutta. The latter are intercalated with carbonaceous shales containing Jurassic Plants as well (KrIshNAN, 1982). Thus the Taltung Formation shows much closer affinities in rock assemblage and sedimentary facies to the rocks of the Peninsular shield than to those of the Himalayan Range.

\section{Amile Formation}

Type locality: Along the upper stream of the Amile river

Thickness: $230 \mathrm{~m}+$

The Amile Formation is distributed almost continuously on both wings of the Tansen Synclinorium, except the upstream area of the Lamachaur river. The name of the formation derives from the Amile river running west near Taltung, along which a most complete section was observed. This formation exhibits a lithostratigraphically diverse sequence (Fig. 16) that consists dominantly of sandstone with subordinate alternating sandstone and shale, shale and limestone. It is largely of nonmarine sediments, but a part of the middle member is originated as marine deposits.

\section{a. Lower Member}

The basal bed consists of an about $10 \mathrm{~m}$ thick white conglomeratic quartz arenite that rests on a distinctly and irregularly eroded surface on the redpurplish shale of the Taltung Formation. On the other hand, at the type locality, the uppermost bed, $30 \mathrm{~cm}$ thick, of the Taltung Formation comprises a hematitic conglomerate. Thus the base of this formation is well defined by a sudden change of lithofacies as well as a disconformable relation between the two formations. The basal bed is mottled purplish red in part. It is followed by the Lower Member consisting dominantly of 20 to $50 \mathrm{~cm}$ thick bedded, white quartzose arenite with some interbeds of black shale (Fig. 16). The sandstones 


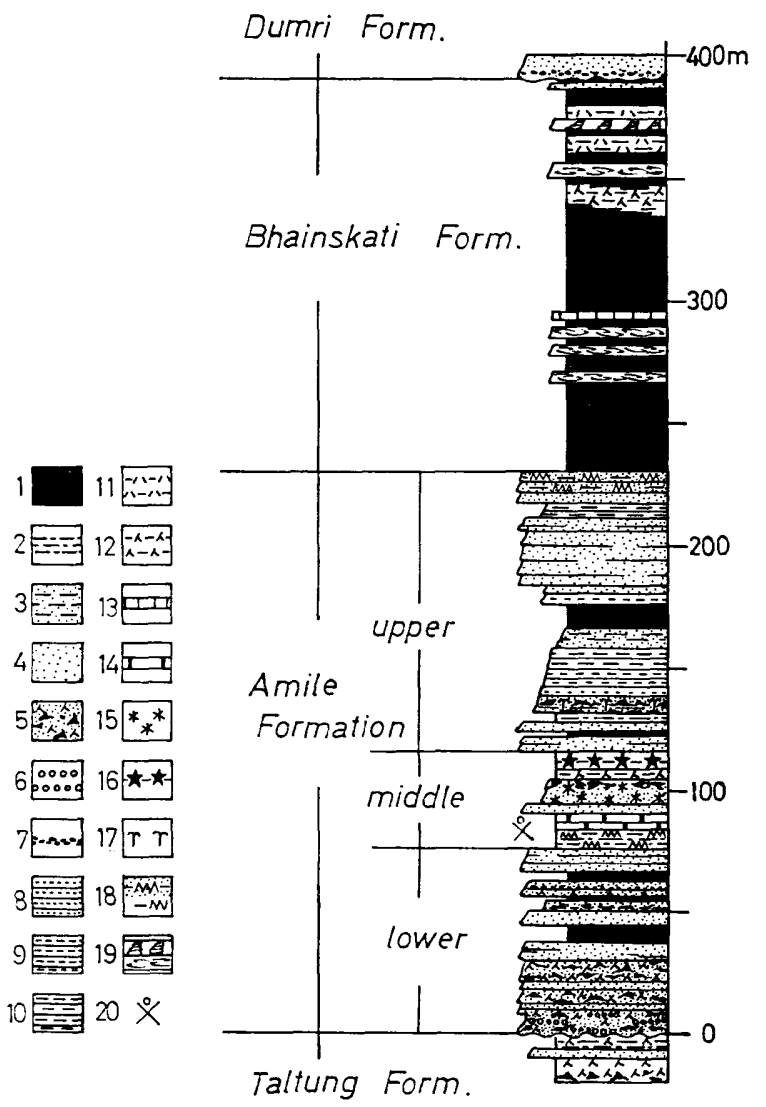

Fig. 16. Lithostratigraphic sequence of the Amile and Bhainskati Formation. 1, black shale; 2, siltstone; 3 , sandstone with shale interbeds; 4 , quartzose sandstone; 5 , ferruginous sandstone; 6 , conglomerate; 7 , shale-pebble conglomerate; $8 \sim 10$, alternating sandstone and shale ( 8 , sandstone predominant; 9 , sandstone and shale equant; 10 , shale predominant); 11 , green shale; 12, red-purple shale; 13, limestone; 14, pinkish limestone; 15, sandstone mottled with hematite; 16 , siltstone with rhodochrosite speckles; 17 , gas-bubble tracks; 18 , bioturbated bed; 19 , beds teeming with molluscan fossils; 20 , horizon of occurrence of fossils in the Amile Formation.

are accompanied with thin pebble layers in which pebbles are scattered or concentrated into linear stripes when they are seen in cross-sctions. Pebbles are mostly less than $5 \mathrm{~cm}$ in diameter, and subrounded to well rounded, and sometimes imbricate. Quartzite and chert pebbles are most abundant, and red- or vermillion- coloured agate is common.

Many of the sandstones of the Lower Member are thoroughly mottled by ferruginous matter. The mottles are irregular in outline and distribution often transecting the stratification surfaces but roughly forming zones subpallal to 
them (Pl. 4, Fig. d). The mottles are coloured light pink to dark reddish brown or reddish purple. In the Lower Member shale beds up to $1.5 \mathrm{~m}$ thick occur at three horizons. They are carbonaceous, and contain fine sand laminae, some calcareous or sideritic layers, and some wood fragments which have been largely replaced by spherical aggregates of pyrite.

\section{b. Middle Member}

The Middle Member is characterized by the presence of fossiliferous siltstone and limestone, and siltstone containing rhodochrosite speckles (Fig. 16). These beds are well traceable as a marker bed throughout all over the area studied. The fossiliferous siltstone beds form a distinct unit up to $20 \mathrm{~m}$ in thickness, being accompanied with thin, lenticular interbeds of argillaceous limestone, and abundantly yield marine bivalves, gastropods, echinoids, corals and some others. These beds are strongly bioturbated. They are overlain by a pink-coloured limestone up to $5 \mathrm{~m}$ thick which consists of 5 to $20 \mathrm{~cm}$ thick bedded micrite with thin partings and lenses of calcareous sandstone. The limestone also contains marine fossils as in the underlying siltstone.

Another bed which characterizes the Middle Member is quartzose arenite that includes dark-grey to black hematite pisolites and speckles as large as $\mathbf{0 . 5}$ to $1 \mathrm{~cm}$ in diameter. This bed is followed by a red-purplish shale. The top of the Middle Member is defined as a $4 \mathrm{~m}$ thick siltstone that abundantly contains rhodochrosite speckles and stringers. In the upper reaches of the Tinau and Amile rivers, these manganese speckles are so densly packed as to form a rhodochrosite bed.

\section{c. Upper Member}

The Upper Member is also dominated by quartzose sandstone, but is distinguished from the underlying members by intercalations of thin-bedded alternation of carbonaceous muddy sandstone and carbonaceous shale. The quartzose sandstone itself is much muddy as compared with that of the underlying members and is commonly accompanied by thin shale interbeds. Many of the muddy sandstone beds are sideritic or hematitic and on weathering assume a reddish brown colour. A carbonaceous and muddy sandstone bed intercalated in the alternating beds of sandstone and shale at a level about $30 \mathrm{~m}$ above the rhodochrosite bed stated contain many gas-bubble tracks or gas-expansion holes (Fig. 16).

The uppermost part of the Amile Formation comprise a bioturbated, carbonaceous muddy sandstone containing coalified wood fragments (Fig. 17). Bioturbation is particularly remarkable in the top bed as much as $1 \mathrm{~m}$ in thickness, in which two layers, each of 10 and $30 \mathrm{~cm}$ thick, are completely stired by burrowing organism and have resulted in complicately interwined sandpipes (Fig. 17). On the top surface a large trail, $45 \mathrm{~cm}$ wide and cver $3 \mathrm{~m}$ long was observed.

\section{d. Mode of Occurrence of Fossils, Age and Correlation}

Highly bioturbated, calcareous, sandy siltstone with thin interbeds and 


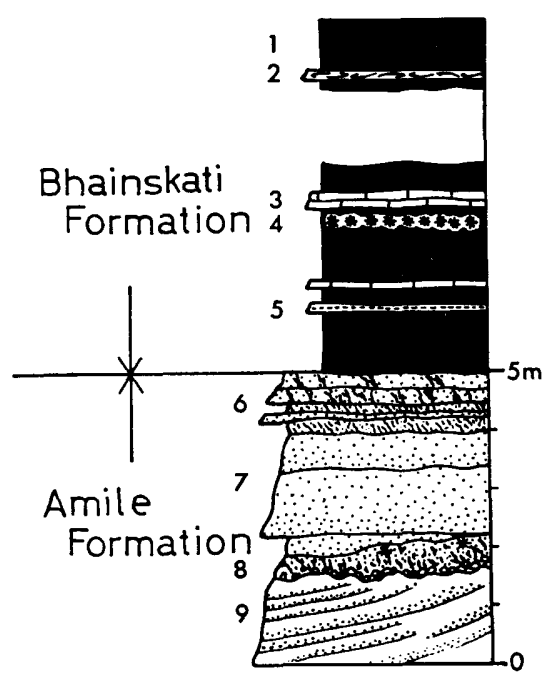

Fig. 17. Detailed columnar section showing the stratigraphic relationship between the Amile and the Bhainskati Formation at the type locality of the Amile Formation along the Amile river. 1, black shale; 2, calcareous shell bed; 3 , calcareous mudstone with carbonaceous fragments; 4 , pyritiferous black shale; 5 , bioturbated sandstone; 6 , intensely to moderately bioturbated, carbonaceous sandstone; 7, carbonaceous, massive quartzose sandstone; 8 , pyritiferous, bioturbated, carbonaceous sandstone with a pebble layer at the base; 9 , tabular crossbedded quartzose sandstone.

lenses of impure limestone and the overlying argillaceous limestone in the middle part of the Amile Formation (Fig. 16) contain abundant bivalve and gastropod shells, and some corals and vertebrate remains (Table. 2). These rocks are, however, so compactly consolidated that it is difficult to separate fossil specimens from the matrix. Besides, the fossil themselves are too fragmentary and badly preserved to be readily identifiable. So that, the age of the Amile Formation can be only determined by its stratigraphic position indicating the Amile to be younger than the late Jurassic to early Cretaceous Taltung Formation, upon which it rests disconformably, and older than the middle Eocene Bhainskati Formation which rests upon it conformably. It should be noted that the Amile yields screleactinean corals as in the probably Jurassic-Cretaceous Tal Formation of the Kumaon Lesser Himalayas. Thus the Amile is probably assigned to Cretaceous to earliest Tertiary in age.

In addition to the fossils indicated in Table 2, some larger foraminifers were recognized in the limestone. A float of sandstone teeming with ostreid shells was also found in the upper reaches of the Tinau river. Further investigations would be able to add better specimens favorable to age determination.

The Amile Formation is largely of nonmarine sediments, but only the fossili- 
ferous beds in the middle part are distinctly assignable to marine origin. In this respect, the Amile still much similarities in lithic characters to the Upper Tal and the Upper Gondwana rather than the correlative Cretaceous-early Tertiary rocks in the Higher Himalayan Range which are predominantly of marine origin.

\section{Bhainskati Formation}

Type locality: Along the Bhainskati river, south of Dumri

Thickness: $160 \mathrm{~m}$

The Bhainskati Formation is well exposed in the southern wing and on the eastern and western corners of the Tansen Synclinorium, but is found only as a few small inliers in the northern wing. This formation is one of the most distinctive beds among the geologic sequences in the Lesser Himalayas, because of its unique lithofacies consisting largely of black shale containing abundant marine fossils. It conformably lies on the Amile Formation with an abrupt change of lithofacies (Figs. $16 \& 17$ ), and the boundary between these two formations is sharply demarated with a marked topographic contrast by the differential erosion of the hard quartzose sandstone and the overlying softer shale.

\section{a. Lithology}

The Bhainshati Formation is made up largely of black shale with many, thin, calcareous and fossiliferous interbeds in the middle part and varicoloured, mainly green and red-purplish shale and red iron beds in the upper part. This sequence and lithofacies of these rocks are persistent all over the extent of this formation. The black shale has no distinct stratification planes and commonly contains carbonaceous flakes and coalified wood fragments, the latter occasionally intensely pyritized. Bioturbation was commonly found in shales when the rock surfaces are wet and polished by river water. In particular the shales directly overlying and underlying the fossiliferous beds are considerably bioturbated.

In the interval between 40 and $90 \mathrm{~m}$ above the base of the Bhainskati Formation are many fossil beds or fossiliferous beds (Figs. $16 \& 19$ ), which contain a large number of shells of bivalves or gastropods or larger foraminifers. Not a few of these beds can be called shell limestone or coquinite. Although the contained fauna has not yet been studied in detail, in each bed it is very restricted in species numbers, but individual species attains a great number. In some beds fragmentary bones of vertebrates were occasionally found. Concretionary interbeds containing elongate, calcareous nodules as much as 30 $\mathrm{cm}$ thick and $3 \mathrm{~m}$ long occur at some horizons (Pl. 5, Fig. c) and are extensively traceable.

The upper few tens of meter of the Bhainskati Formation consist mostly of green and reddish-purple shales with subordinate hematitic iron beds. A representative sequence at the type locality is shown in Fig. 18. Green and reddish-purple shales are remarkably similar to each other in lithologic character, and the colour difference is thought to be simply due to the ratio of ferrous to ferric ions. As a whole red-purplish shales surpass green shales in the number 

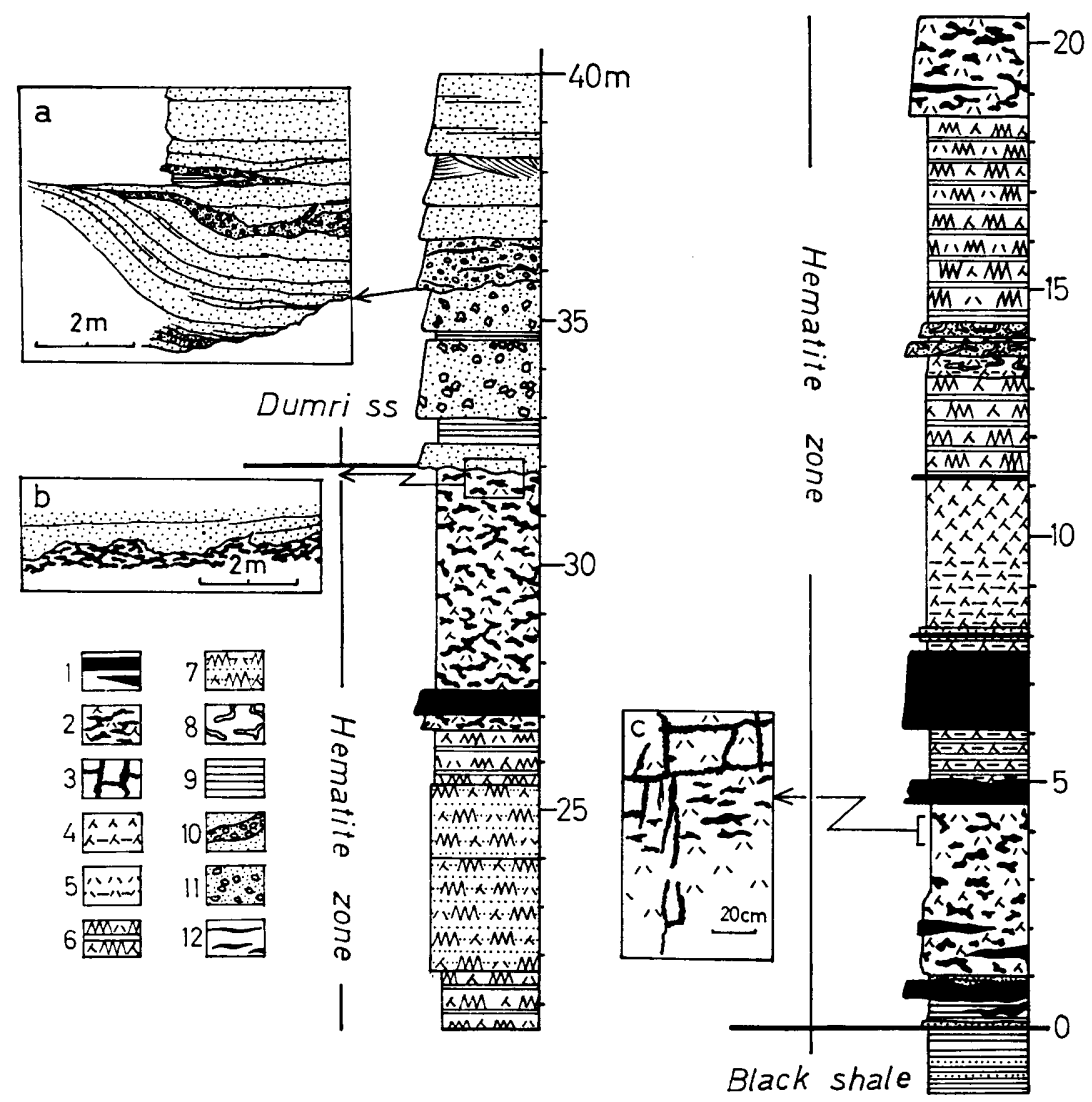

Fig. 18. Detailed columnar sections of the uppermost part of the Bhainskati Formation and the basal part of the Dumri Formation. a, wedge-bedding and intraformational shale-pebble conglomerate; $b$, erosion surface on the top bed of the Bhainskati Formation. 1, oolitic hematite mottles; 3 , hematite along a joint system; 4, red-purple shale; 5 , green shale; 6 , bioturbated green and red shale; 7 , bioturbated sandy shale; 8 , sand pipes; 9 , black shale; 10 , intraformational shale-pebble conglomerate; 11 , calcareous, shale-pebble conglomerate; 12 , hematite beds and lenses.

of beds and the thickness. No regular order of sequence between these two colours has been recognized. Some intervals are uniformly coloured alternately with the colour boundary following the bedding, whereas in some other intervals the red-purplish shales are irregularly and gradually replaced by green shales, or contain bands or groups of bands and nodules of green shale with an abrupt contact. Some of green shales contain irregular, red-pigmented mottles and joint-filling hematite bands (Fig. 18c). At the middle of the upper part are intensely bioturbated sandstone beds as much as $1 \mathrm{~m}$ thick, which have sinuous red-pigmented sandpipes.

Hematite beds occur at several horizons in the upper part and are extensively traceable, although the thickness of beds and the iron content are locally varied. At the type locality more than six hematite beds were recognized. They 
vary in thickness between $5 \mathrm{~cm}$ to $2 \mathrm{~m}$ and consist chiefly of hematie ooids with subordinate quartz grains and a hematite or chamosite-like light green clayey matrix. Hematite ooids range in size from 0.5 to $2 \mathrm{~mm}$ and contain quartz as nuclei. In the western area hematite beds become thinner and fewer in the number of beds, but instead there are some siderite oolites containing gastropods and bivalve shells.

\section{b. Mode of Occurrence of Fossils, Age and Correlation}

Well preserved, large foraminiferal fossils were discovered at several localities from muddy limestone beds (Fig. $5 \mathrm{BN}$ ) that are at levels about 30 to $50 \mathrm{~m}$ above from the base of the Bhainskai Formation. These beds extends from Tal-
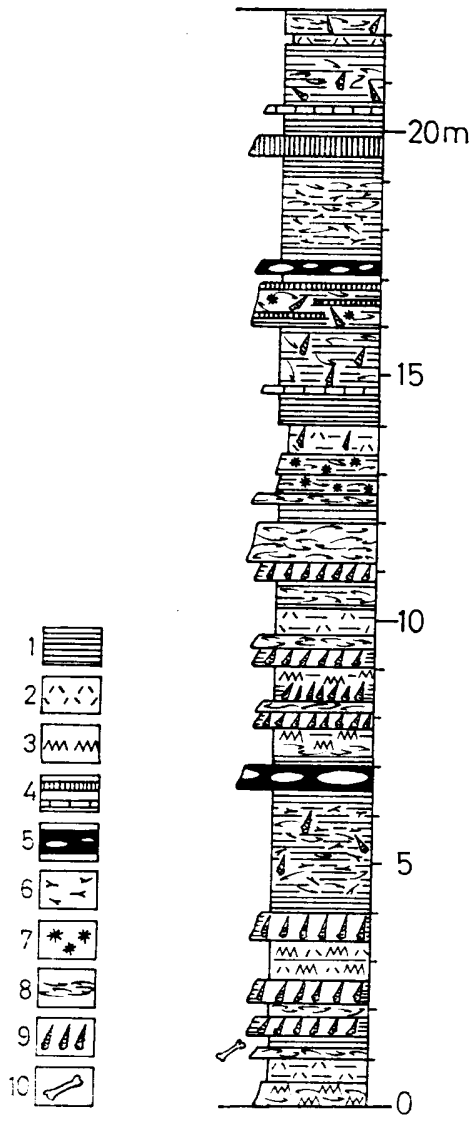

Fig. 19. Detailed stratigraphic section of the middle part of the Bhainskati Formation along the Bhainskati river, showing the occurrence of fossiliferous bed. Loc. BMV3 in Fig. 5. 1, black shale; 2, green shale; 3 , bioturbated beds; 4 , sideritic bed; 5 , calcareous concretions; 6 , carbonized wood-branch fragments; 7 , spheroidal pyrites; 8 , bivalve fossils; 9 , gastropod fossils; 10 , vertebrate fossils. 
tung to the tributaries of the Badahare river, although they are as thin as 5 to $10 \mathrm{~cm}$. Small coalified branch remains and fragmentary gastropods are scattered in these beds. Foraminifers also occur from some silty shales and calcareous concretionary beds. From these beds Nummlites beaumonti d'ARCHAIAC and HeIme and Assilina papillata NutTle were idenified. These indicate middle Eocene age. Thus, as a whole the Bhainskati Formation must range from middle to late Eocene.

As mentioned above, the lower part of the Bhinskati Formation includes a large number of fossil beds, each of which is often full or abound with either bivalves or gastropods. It is interesting that these monopolized fossil beds occur alternatingly as seen in Fig. 19. Most of bivalves are disjoined. The bivalves and gastropods at hand are being studied at present. Some vertebrate bones were also obtained from these shell beds, and of special interest is that land mammal fossils occur along with marine fishes.

Marine Eocene beds that are characterized by Nummulites and allied larger foraminifers are widespread in the Sind, Bulakistan and Salt Range. In these regions the middle and upper Eocene beds containing Nummulites beaumonti and Assilina papillata occupy the middle and upper part of the Kirtar Series which is largely composed of massive limestone. The complete sequence of the Eocene beds is also seen in Assam, where the middle and upper Eocene are represented by the Nurpush sandstone with subordinate calcareous bands, the Prang limestone as much as $200 \mathrm{~m}$ thick, and the Kopili Formation consisting of alternations of shales and sandstones with bands of calcareous sandstones and shales. The Bhinskati Formation is different in lithofacies from the correlatives of these regions.

In the Himalayan Range fossiliferous Eocene beds are distributed discontinuously along the foothills of the Lesser Himalayas. In the Garhwal and Kumaon areas, the Eocene beds, called the Subathu, are represented by a basal bed of pisolitic laterite and bauxite, pyritiferous shale with interbeds of coal and ironstone, grey and olive-coloured shale, and nummulitic limestone with some olive shale in ascending order. The Subathu Formation has been assigned to

\section{Explanation of Plate 5}

Fig. a: Impressions of fossil trunks on the basal surface of a sandstone bed of the Dumri Formation. The one on the right has branches and is over $6 \mathrm{~m}$ in length. Note their disposition indicating prefered orientation. Bhainskati Khola.

b: Conspicuous wedge bedding and cross-stratification of sandstones in the lower part of the Dumri Formation. Conglomerate(c) containing reworked debris of underlying black shale, sandstone, hematite and carbonaceous wood fragments as much as $1 \mathrm{~m}$ long are interbedded.

c: Large, calcareous concretions containing molluscs and foraminifers being disposed parallel to the bedding plane of fossiliferous shales. Bhainskati Formation, Bhainskati Khola.

d: Oolitic hematite bed (left) and irregularly mottled hematite bed (right) at the uppermost part of the Bhainskati Formation. Bhainskati Khola. 

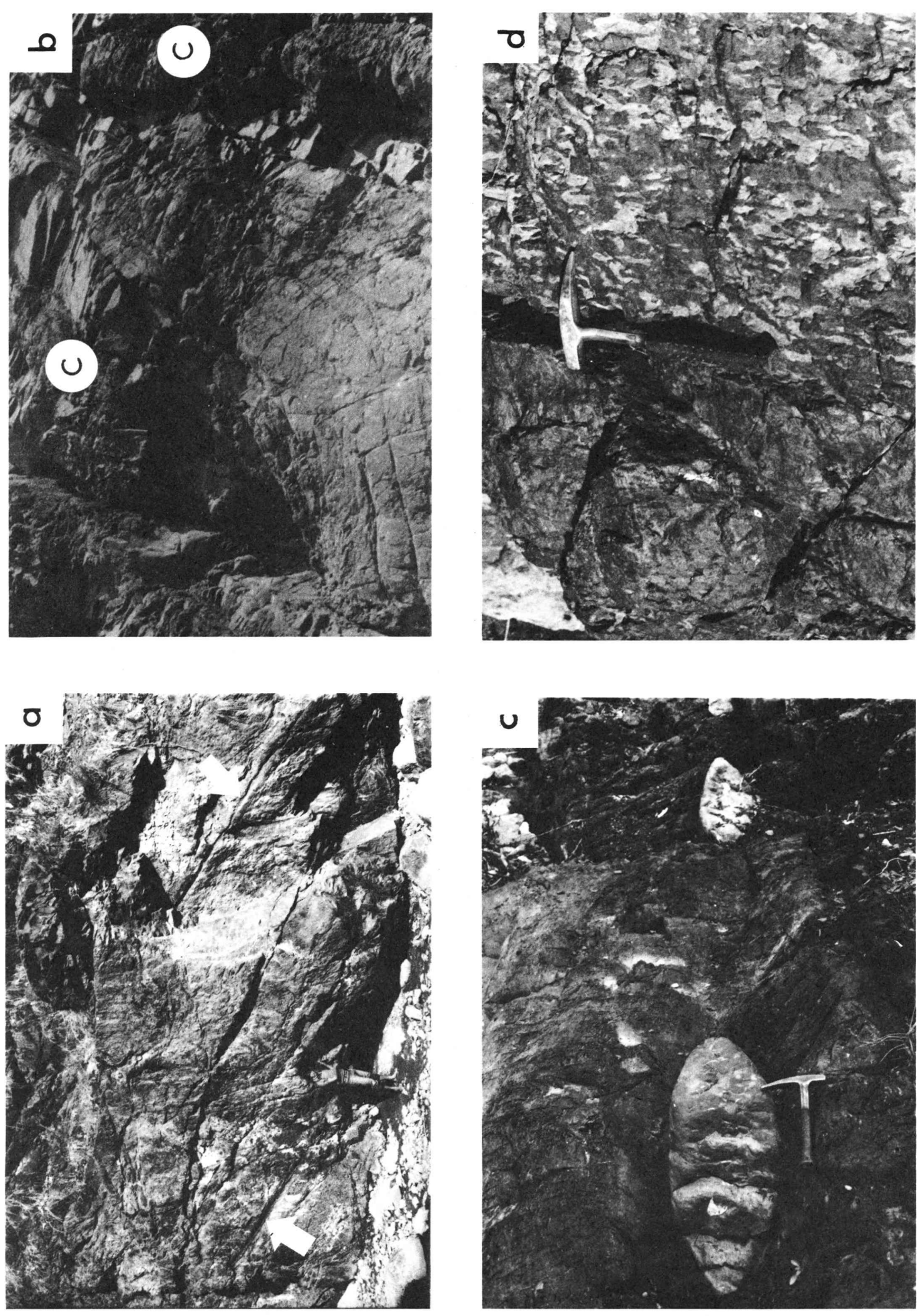

H. SAKAI: Geology of the Tansen Group 

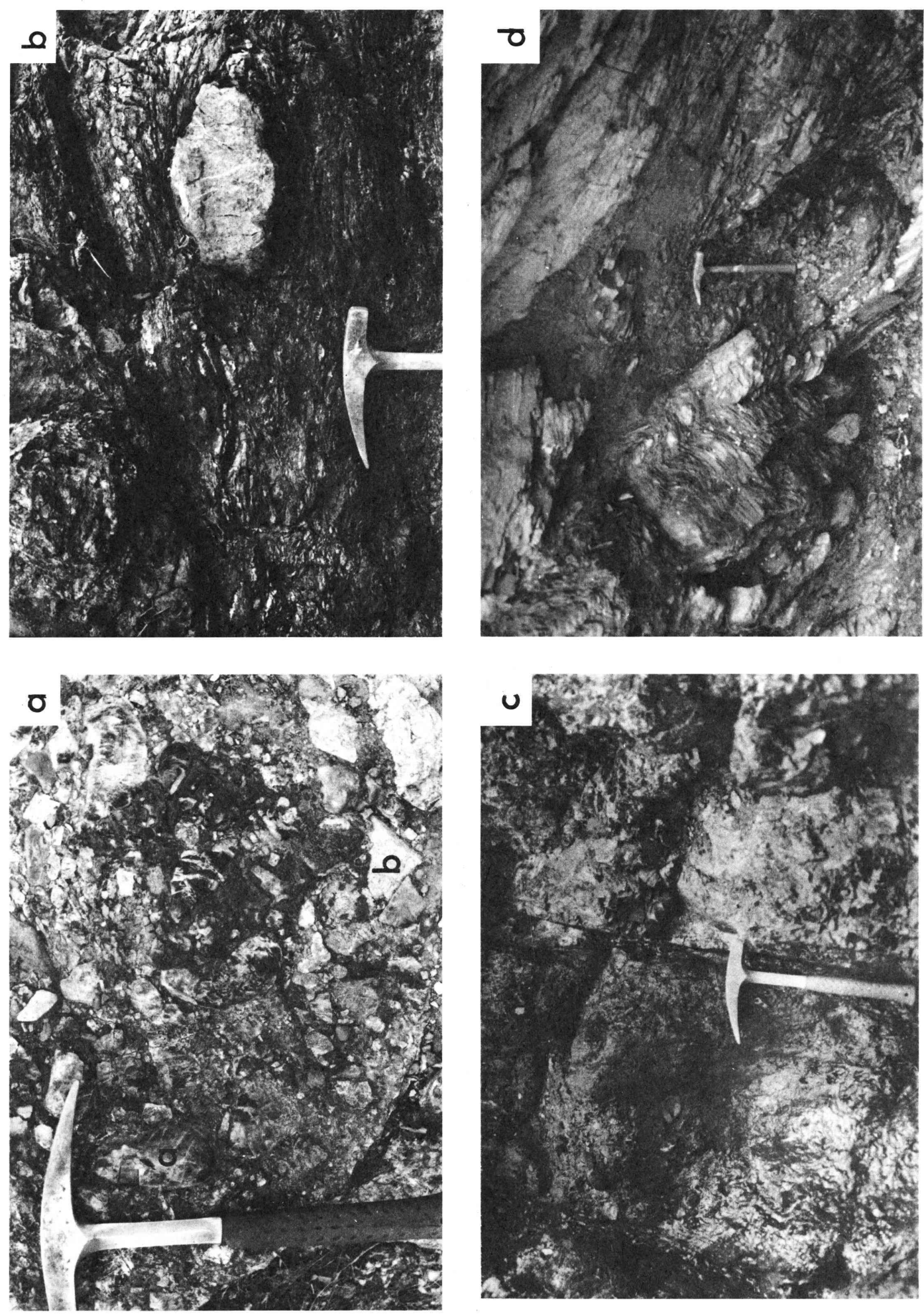

H. SAKAI: Geology of the Tansen Group 
the Laki Series of early Eocene age on the basis of Nummulites and other larger foraminifers which occured from limestones in the upper part (VALDIYA, 1980). However, as Nummulites beaumonti is reported to occur from the Subathu (WADIA, 1981), the part of the Subathu may be correlated with the Bhinskati. The continuation of the Subathu to the east has been confirmed to be present in the Surkhet Valley, Western Nepal (TIWARI and GuPTA,, 1976), where the Eocene beds consist of black carbonaceous shale with interbeds of limestone containing larger foraminifers. This bed is similar in lithologic character to the main part of the Bhainskai. Nummulites sp. and Assilina sp. known from the Dan and the Bhainskati areas (SHARMA, 1977) were the first record of fossils from the present area, and the beds containing these foraminifers are included in the Bhainskati Formation.

\section{E. Dumri Formation}

Type locality: Along the Bhainskati river at Dumri Thickness: $725 \mathrm{~m}$.

\section{Lithology}

The Dumri Formation that occupies the top of the Tansen Group disconformably overlies the Bhainskati Formation with a distinct erosion surface and an abrupt change of lithofacies (Fig. 18b). It comprises a thick series of medium-grained, bluish-grey quartzose sandstones interbedded with red and green shales (Fig. 20). Shale occur more often in the lower to the middle part than in the upper part, and the sandstone-shale ratio becomes larger up-sections, although no remarkable changes of lithic character are recognized throughout the sequence. Sandstones of this formation are quartzose wacke with a little amount of fine carbonaceous grains, and vary in thickness between 0.1 to $6 \mathrm{~m}$. Some beds of sandstone exhibit wedge-shaped cross-bedding, but those as much as a few meters thick are generally massive and scarcely have stratification

\section{Explanation of Plate 6}

Fig. a: Basal conglomerate of the Sisne Formation in the Besarka Outlier. All pebbles and cobbles are derived from the underlying Kerabari Formation. a, chert; b, oolitic dolomite. Besarka, upper stream of the Arung Khola.

b: Strongly sheared argillite of the rupture zone beneath the Palpa Klippe of the Angha Khola Formation. Disrupted sandstone lense is of the Amile quartzite and the sheared argillite are derived from shale of the Bhainskati Formation. Surangtung Khola.

c: Sharp fault contact between the Sisne Diamictite (left) and the Kerabari Dolomite (right) along the southern boundary fault of the Tansen Synclinorium. Kurman Khola.

d: Fault contact between the well-cleaved Sisne Diamictite (right) and the Ramdighat Slate of the Kali Gandaki Group (left). Note the cleavages on both sides cross each other at a right angle. Muslang Khola. 


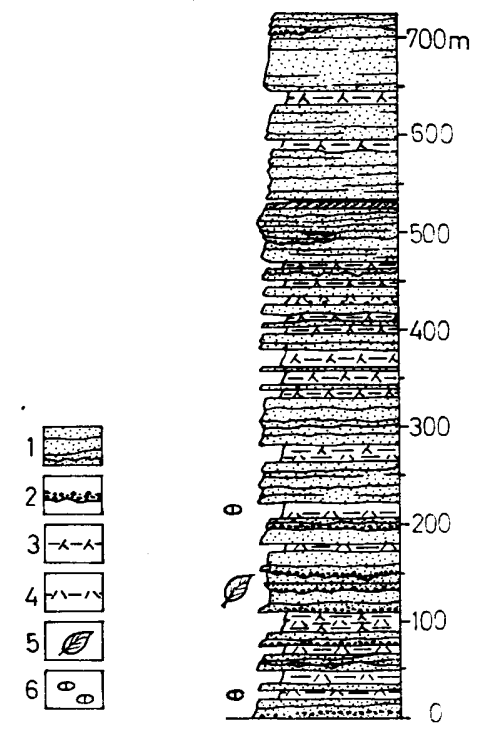

Fig. 20. Lithostratigraphic section of the Dumri Formation. 1, quartzose sandstone; 2 , intraformational shale-pebble conglomerate; 3 , red-purple shale; 4 , green shale; 5 , horizon of occurrence of plant fossils; 6 , horizon of occurrence of calcareous shalepebbles.

planes, although load casts were rarely found at their base. Ripple marks were recognized on the surface of thin-bedded sandstones.

Sandstones lying at 1 to $4 \mathrm{~m}$ above the base of this formation contain scattered angular clasts of calcareous shale (Fig. 18), and the following bed that rests on an irregularly channeled surface shows large-scale cross-bedding and is accompanied with wedge-beds containing calcareous shale clasts (Fig. 18a, Pl. 5, Fig. b). There are also several intraformational shale-pebble conglomarate and conglomeratic sandstones in which tabular clasts of shale up to a few tens of centimeters across are embedded in a sandy matrix. These shale pebbles are often noticeably abundant at the basal part of the sandy beds, under which scour channels cut into the underlying shale or sandstone bed were commonly recognized. In these conglomerate beds coalified wood fragments and trunks are commonly accompanied. Some trunks reach up to $6 \mathrm{~m}$ in length and $60 \mathrm{~cm}$ across (Pl. 5 Fig. a).

A notable feature of the Dumri Formation is that almost all of the shale interbeds are coloured green or red. Those in the lower part are mostly green, whereas those of the upper assume a red colour (Fig. 20). But in some beds both colours are gradually or abruptly changed toward vertical direction to each other. Particularly in some red beds in the middle part green patches, nodules or bands usually with an abrupt colour contact are present, probably due to bleaching of red beds by interstratal percolation of reducing water. Bioturbation is common in shales and is easily recognized by mottled structures or sinuous tubes expressed by the difference of colours. 
The rhythmic sequence of sandstone and shale, and the common occurrence of red beds, scour channels beneath sandstone and conglomerate beds and associated intraformational shale-pebble conglomerates, wood fragments including trunks prominent cross- or wedge bedding of sandstones suggest that the Dumri is assigned to fluvial flood-plain deposits that accumulated rapidly. The Dumri Formation exhibits a sudden change of lithofacies from the underlying Bhainskati, and is, as a whole, characterized by much preponderance of coarse sediments, remarkable increase of a bed thickness as well as the whole thickness, and an upward increase of massive beds. These features suggest that, during the deposition of the Dumri, the source area from which the clastics were derived was being uplifted. In addition, very significant is that the cross-bedding and imbrication of pebbles in this formation demonstrate the current direction from north to south in the direct opposition to those of the underlying formations.

\section{Mode of Occurrence of Fossils, Age and Correlation}

No fossils significant for age determination were obtained from the Dumri Formation, although vertebrate bone fragments and carbonized plant remains including leaves, trunks and branches were found. The trunks and branches are commonly enclosed in the lower part of sandstone beds and in shale-pebble conglomerates. Large trunks as much as $5 \mathrm{~m}$ long and $30 \mathrm{~cm}$ wide at maximum were found (Pl. 5, Fig. a), but these wood remains are so considerably squashed that annual rings and other tissues cannot be observed.

The Dumri Formation is younger than the middle to late Eocene Bhainskati Formation which it overlies disconformably, but its definite age is not known by means of fossils. It is known that in the Himalayan Range including the Lesser Himalayas remarkable uplift affected the whole area after the Eocene marine incursion and resulted in intensive denudation or lack of sedimentation in Oligocene time. In the Sub-Himalayan range the latest Oligocene and early to middle Miocene Murrees Group consisting of very thick, mostly brakish- to fresh-water sediments rests directly on the Eocene Subathu Formation. The Dumri Formation is similar in lithofacies to the Murrees as a whole, but a striking similarity in lithostratigraphic sequence is seen between the Dagshai Formation of the Simila Himalayas and the Dumri. According to KRISHNAN (1982), the Dagshai is correlated with the Lower Murrees and comprises a series of grey or purplish, fine- grained quartzitic sandstones with red to purplishbrown, mottled clay interbeds. The sandstones are massive, having no stratification planes and gradually increase in proportion and thickness in the upper part. These features are entirely common to those of the Dumri, although a disconformable relation to the underlying Eocene beds is not apparent in the Simla area, but is clear in this area. Thus the Dumri Formation is probably referable to early Miocene in age.

\section{B. Kali Gandaki Group}

The Kali Gandaki Group is here designated as the thick sequence consisting of carbonate rocks, quartzite and argillaceous rocks and underlying the Tansen 
Group. It is distributed in western Central Nepal with a width of $50 \mathrm{~km}$, and is bounded by the Himalayan Gneiss with the Main Central Thrust on the north and by the Siwalik Group with the Main Boundary Thrust on the south (Fig. 3). Thus, this group occupies the main part of the Lesser Himalayas in Central and Western Nepal. In the mapped area it is separated by the Phalebas Thrust (ARITA et al., 1982) into two parts; the northern part that belongs to the "Chail Nappe" named by FUCHS and FranK (1970) is made up of thick quartzite and phyllite with some amphibolite; the southern belt is composed of limestone, dolomite, quartzite, phyllite and slate and embraces the Tansen Synclinorium comprising the Tansen Group and overthrust sheets of the Kali Gandaki Group.

The base of this group cannot be defined, because its exposed lower limit is faulted. Total thickness of the group measured about $8000 \mathrm{~m}$, and throughout the thickness no stratigraphic discontinuities were recognized. This group is in general weakly metamophosed in the lower part, the argillaceous rocks being coverted into phyllite, and shows a distinct decrease in metamorphic grade upward. Except stromatolites, no fossils were obtained, so that the age of this group is uncertain. It can be said, however, that this group is older than late Palaeozoic, since it underlies the Sisne Formation of Carboniferous to Permian age.

The Kali Gandaki Group is tentatively divided into two formations, the lower Angha Khola and the upper Kerabari Formation. In the following, brief descriptions of the lithostratigraphic sequence are given:

\section{Angha Khola Formation}

This formation consists chiefly of phyllite, quart arenite and quartzose sandstone with subordinate dolomitic stromatolites and oolitic dolomite. It crops out mainly on the northeastern and northwestern sides of the Tansen Synclinorium and is also very narrowly exposed along the Main Boundary Thrust in the western part of the mapped area. The type locality is designated as the section along the Angha Khola (river) in the northeastern part (Fig. 3), but the rocks exposed there are all overturned, so that the continuous normal sequence along a tributary of the Nisti Khola in the eastern extremity of the mapped area was chosen as a reference section.

The Angha Khola Formation attains more than $3000 \mathrm{~m}$, and no remarkable lateral changes of lithofacies have been observed. It is divided into seven lithostratigraphic units as follows in ascending order:

1. The lowermost Heklang Green Phyllite, more than $600 \mathrm{~m}$, is a monotonous sequence of very thin laminated to 1 to $3 \mathrm{~cm}$ thick banded phyllite with some thin calcareous sandstone beds.

2. The following Bajadi Phyllite attains $500 \mathrm{~m}$, and is comprised mainly of reddish-purple phyllite with lesser amounts of quartz arenite and some intercalations of stromatolite limestone and oolite. Shale-pebble conglomerate layers are commonly associated or interbedded with the sandstones. These beds show an abrupt lithologic change in sequence to one another and a fairly remarkable variation in thickness ranging from a few centimeters to a few meters. 
3. The Virkot Quartzite consists of an about $125 \mathrm{~m}$ thick, light-pink to light-green quartzose arenite. It often exhibits ripple marks and cross-beddings of various types.

4. The Chappani Grey Slate, about $450 \mathrm{~m}$ thick, is made up mainly of lightgrey, thin laminated, calcareous slate with some beds of stromatolite that forms small, vertical columns. The base of this unit is defined by a silicified stromatolite bed, which shows a very rugged weathering surface. Some beds of black, light-purple and light-green slate are interclalated in the lower part.

5. The Khoraidi Dolomite, $350 \mathrm{~m}$ thick, is predominantly dolomitic stromatolites and is occasionally accompanied by oolite and quartzose sandstone. The stromatolites are various in form and size, being commonly cabbagelike to moundlike, and attaining $2.5 \mathrm{~m}$ at maximum diameter. This unit forms a good marker bed throughout the extent of the Kali Gandaki Group in the mapped area.

6. The Saidi Khola Beds comprise a 250 to $300 \mathrm{~m}$ thick sequence of interbedded quartzose arenite and shale, with sandstone predominating in the lower part whereas shale prevailing in the upper. The bed thickness also varies from 50 to $20 \mathrm{~cm}$ thick bedded in the lower to much thinly bedded in the upper. Thus this unit shows a fining- and thinning-upward sequence and passes into the overlying Ramdighat Slate unit through some thickness of shale with thin bioturbated sandy layers.

7. The Ramdighat Slate occupies the uppermost $775 \mathrm{~m}$ thick sequence of the Angha Khola Formation, and is lithologically subdivided into three parts; the lower part of black and green slate as much as $100 \mathrm{~m}$ thick, the middle part attaining $500 \mathrm{~m}$ in thickness and consisting of laminated to thin banded interbeds of purplish or light-greenish slate and white dolomite and limestone, the latter being a few $\mathrm{mm}$ to $1 \mathrm{~cm}$ thick for each band and up to $10 \mathrm{~cm}$ thick for a group of bands; the upper, $150 \mathrm{~m}$ to $175 \mathrm{~m}$ thick, comprising a light-green to milkcoffee brown, calcareous slate with thin bands of limestone.

\section{Kerabari Formation}

A several $\mathrm{km}$ wide rocky dolomite terrain protruded prominently from the lower elevations and slopes of the Siwaliks extends from eastern Nepal to western Nepal on the northern side of the Main Boundary Thrust. One of almost complete sections crossing the terrain is seen along the Tinau river between Tansen and Butwal, where the dolomite forms a steep cliff around a village of Kerabari, thus Nepalese geologists have called it the Kerabari Dolomite, although Kerabari is so small that is not shown on the 1 inch-1 mile topographic map. The name Kerabari Dolomite is, however, herein elevated up to a rank of formation and is designated as including not only the dolomite but also associated rocks. In the mapped area, the Kerabari Formation continuously extends on the northern side of the Main Boundary Thrust as mentioned above, but also occurs isolatedly on the northern side of the central part of the Tansen Synclinorium.

The Kerabari Formation is graditional from the Angla Khola Formation through calcareous slate with thin limestone laminae, so that the boundary is artifically placed at the base of first occurrence of bedded limestone. The Kera- 
bari Formation measures a little more than $2000 \mathrm{~m}$ in thickness and is composed mostly of grey, thin to very thick bedded dolomite with limestone at the basal part and thin interbeds of chert in the middle and upper part. No terrigenous clastic rocks attaining an appreciable thickness are intercalated. Laminated stromatolites occur at many levels. Bedding surfaces are generally distinct and are of parallel bedding.

This formation is lithostratigraphically divided into four parts as follows:

1) The lowest part is an about $100 \mathrm{~m}$ thick, monotonous sequence of darkgrey to black, platy bedded, argillaceous limestone. A notable feature is to have fine parallel laminations, which are very useful to distinguish this member from the top beds of the underlying Angha Khola Formation.

2) The lower part is platy bedded dolomite including fine flat- to undulatory, rhythmical interlayering of dark-grey and lighter laminae probably of algal origin. At the uppermost part there occurs about $7 \mathrm{~m}$ thick, massive intraclastic dolomite. In the upper stream of the Badahare river carbonaceous seams are occasionally inercalated in the upper part. On some bedding surfaces ripple marks and flute marks were recognized. These sedimentary structures invariably show current directions from southeast to northwest or from east to west.

3) The middle part is composed principally of $5 \mathrm{~cm}$ to $1 \mathrm{~m}$ thick, evenly laminated or sheeted, grey stromatolitic dolomite which is characterized by frequent intercalations of thin bands and lenses of chert. Alternating beds of thin dolomite and chert also occur at some levels. There commonly occur intraclastic dolomite beds which contain scattered small clasts or breccias of chert. Ripple marks, flute casts and convolute laminations are rarely found.

4) The upper part is also comprised of a few to $3 \mathrm{~m}$ thick beds of grey dolomite, and is characterized by many interbeds of reddish-purple to pink dolomite and shale. Thin beds of quartzose sandstone, oolite and chert are rarely intercalated. The sandstones contain well-rounded quartz grains and red agate granules. Cross-bedding and graded bedding are occasionally recognized.

\section{Sedimentary Facies}

As mentioned above, the Kali Gandaki Group is an enormously thick sequence consisting chiefly of fine-grained terrigenous clastic rocks in the Angha Khola Formation and mostly of dolomite in the overlying Kerabari Formation. The great thickness of the continued sequence and the great extensity of the beds without appreciable lateral changes of lithofacies indicate that this group was deposited in an widespread basin on a stable basement which continuously subsided. The depositional basin of the Angha Khola was much subjected to the influx of terrigenous materials, but the upward-fining and the marked decrease of clastic sediments and instead the overwhelming increase of carbonates from the upper part of the Angha Khola to the Kerabari suggest that the nearby land masses, which contributed the large amounts of clastic sediments to the Angha Khola, were becoming increasingly very low, or that the inflow of land rivers carrying terrigenous sediment loads were much reduced. 
The Angha Khola Formation is thought to have been deposited on a broad, nearly level plain ranging from a flood plain on shore, via a series of supratidal sabkha-fringing algal zone-intertidal flat, to a very shallow sea. The deposits in a sabkha or a similar supratidal flat which is usually fringed with an algal zone in the intertidal flat are suggested by the dolomite and dolomitic stromatolite association which is exhibited in the middle members of the Angha Khola. The presence of oolites along with stromatolite beds indicates that wave- or currentagitated water conditions existed at least temporarily. On the other hand, thin to thick interbedded sandstone and black shale and associated bioturbated mudstone as those of the Saidi Khola Member is probably assigned to the deposits of a shallow sea environment. The great thickness of thinly interbedded purplish shale, stromatolite limestone and black to grey shale as in the Chappani Member suggests a rather quiet-water deposition, and throughout the Angha Khola time, sea level changes which caused the vast advance and retreat of the environmental belts stated above were generally slight and repeated many times.

The Kerabari Formation shows apparently marked lithologic differences from the underlying Angha Khola Formation in that it is almost devoid of clastic sediments. It is cosidered, however, that this is not due to the profound changes of sedimentary environments, but simply to the decrease of the influx of detrital materials. Because the Kerabari Formation is composed almost exclusively of dolomite, dolomitic stromatolites and black, platy-bedded limestone, the former being referable to the deposits of a supratidal flat, where hypersaline conditions were much prevailed as in sabkha, to an intertidal flat, and the latter one to an intertidal to a very shallow sea. The presence of oolite at some levels also clearly supports the shallow sea deposition.

\section{Geologic Age and Correlation}

The Kali Gandaki Group is unfossiliferous, so that its age can be only circumstantially inferred within wide limits. The Kali Gandaki Group is no doubt older than late Carboniferous because it underlies the Sisne Formation of the Tansen Group of that age, although it cannot be known how much time gap is embraced within the unconformity between the two groups. In connection with this respect, a noteworthy is the occurrence of a several $\mathrm{mm}$ long and 1 to $2 \mathrm{~mm}$ wide plant fragments from many thin beds of black carbonaceous shale in the upper part of the Kerabari Formation. They are too much fragmentary and carbonized to be identified, but the presence of such a clear plant remains suggests that the upper part of the Kerabari may possibly be as young as middle Palaeozoic. I also found that, in the Darsing area located $25 \mathrm{~km}$ north of Tansan, coaly shale beds as much as $30 \mathrm{~cm}$ in thickness associated with black limestone beds more than $50 \mathrm{~m}$ overlies the Darsing Dolomite which can be correlated with the Khoraidi Member.

The prolific occurrence of stromatolites from many levels of the Kali Gandaki Group, especially of the upper half, suggests that the larger part of the group ranges down to Proterozoic. The stromatolites show a wide diversity of forms and sizes. Detailed descriptions and classification of stromatolites of this area 
will be given in another paper, but it can be said at present that, so far as the studied area is concerned, the stromatolites are rather uniform in form and size in each of the stratigraphic units, but are readily distinguishable among them; those of the Chappani Member of laterally linked terete to cylindrical columns about $10 \mathrm{~cm}$ across, those of the Khoraidi Member of bulbous to domal form at-

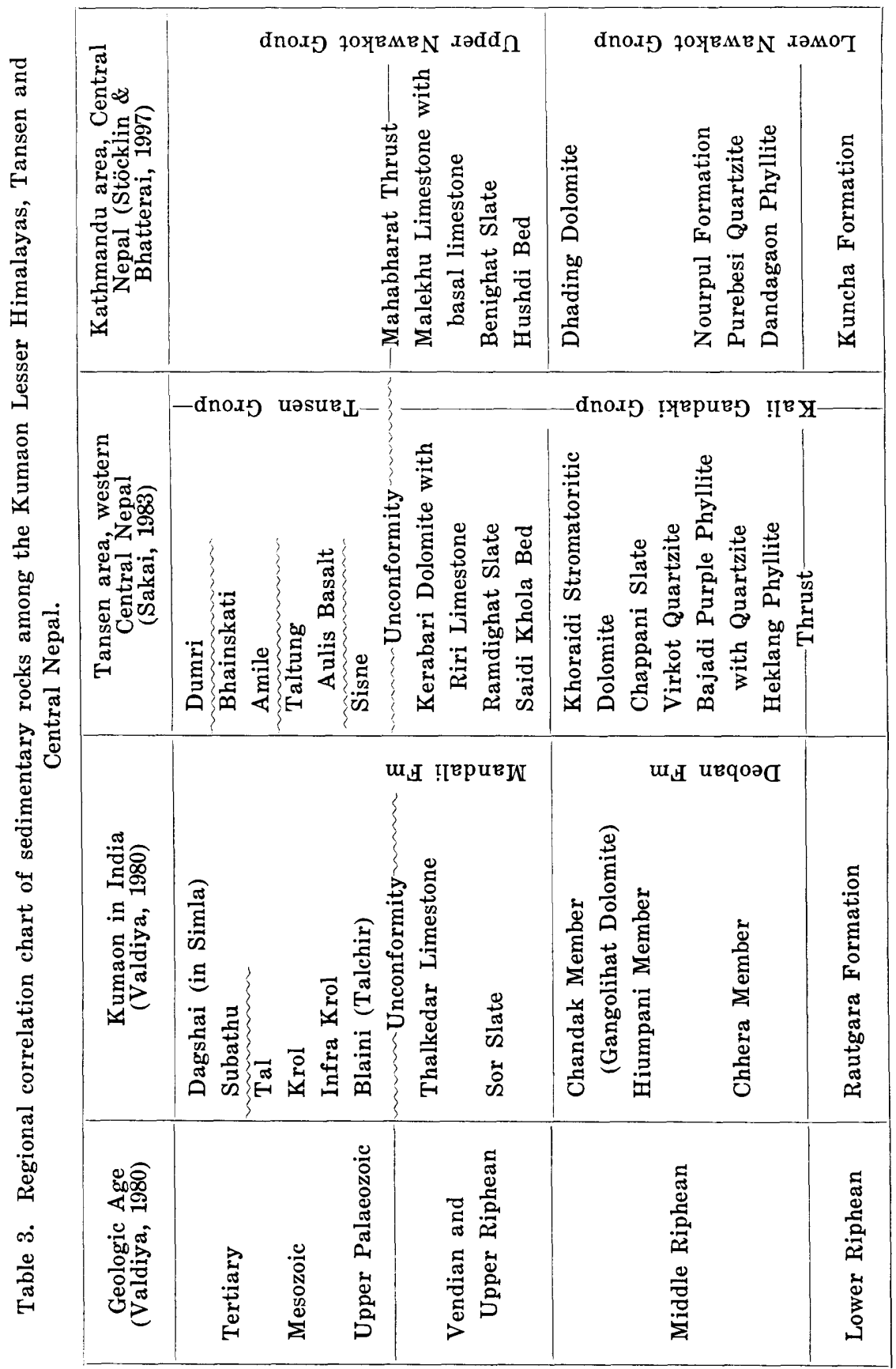


taining as much as $3 \mathrm{~m}$ across and are usually associated above with oolite beds, and in the Kerabari stratiform stromatolites with fine laminae are most common. These differences of stromatolite morphology is very useful for the recognition of stratigraphic levels, and at the same time must be worthy for correlation.

The Angha Khola Formation contains highly bioturbated beds with abundant trails and burrows at many horizons of its middle part. Fossils may be expected to occur from these beds.

On the basis of the similarities of general lithology and stratigraphic sequences, the Angha Khola and Kerabari Formations of the Kali Gandaki Group are correlated respectively with the Deoban and the Mandhali Formations (VALDIYA, 1980) in the Kumaon area in India and with the Lower and the Upper Nawakot Group (StöckliN and BhatTERAI, 1977; STöcKLIN, 1980) in the Kathmandu area, eastern Central Nepal. Although the slight differences in thickness and lithofacies are present between them, the lithostratigraphic sequences of these groups are consistent to one another. However, with respect to the correlation between the units of the lower rank, to which members of the Kumaon squence the Saidi Khola and Chappani Member can be correlated, and whether or not the Virkot Quartzite Member is equivalent in age to the Prebesi Quartzite (StöCKLIN and BhatTARAI, 1977; StöcKLIN, 1980) of the Kathmandu area are uncertain.

\section{Geologic Structure}

The study area belongs to the southern part of the Lesser Himalayas in western Central Nepal, and is composed of a major zone of the Kali Gandaki Group in which the Tansen Group forming an elongate basin-shaped structural trough called the Tansen Synclinorium is embraced. These rocks are interpreted to form a large, southerly verging recumbent fold associated with a thrust formed by stretching of the overturned limb of the fold, and the Tansen Synclinorium to occupy the normal limb of the downwarped syncline on the footwall side, as diagramatically shown in Fig. 21.

Major thrusts and faults, axes of major folds of the study area are shown

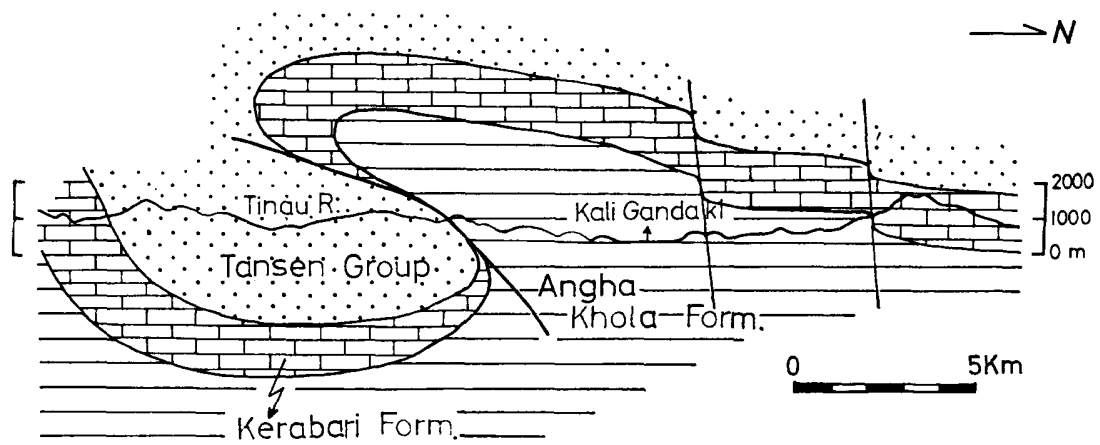

Fig. 21. Schematic profile of a huge recumbent fold and the Tansen Synclinorium. 

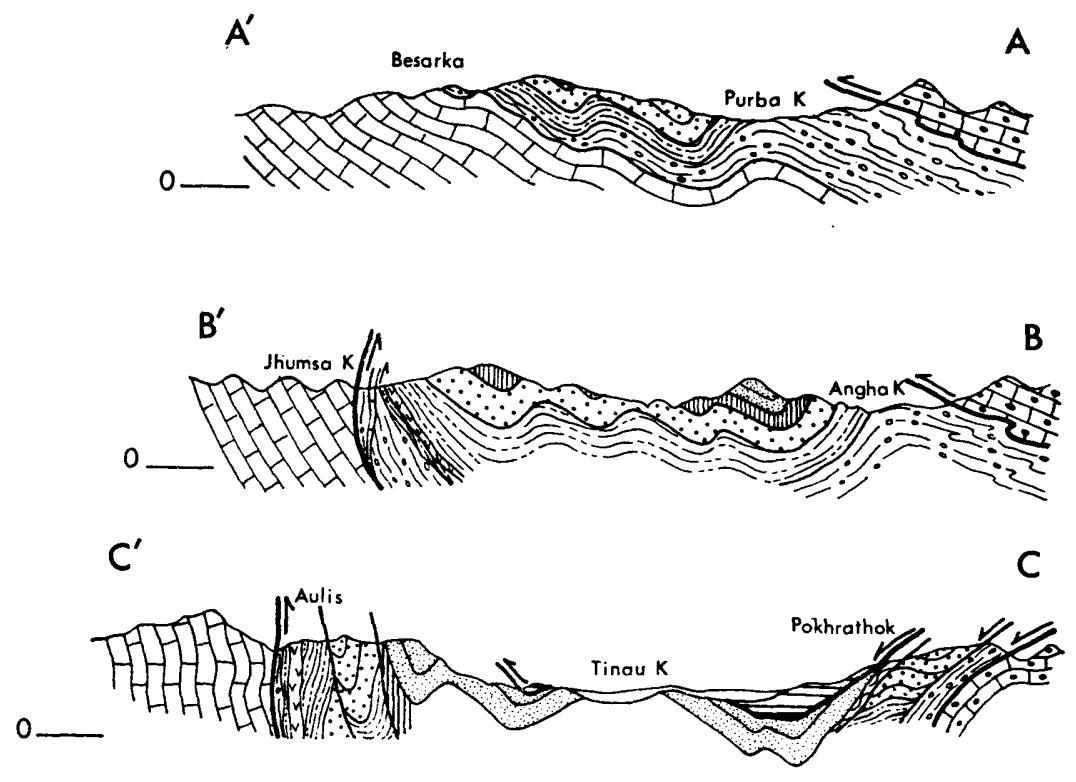

$D^{\prime}$

D
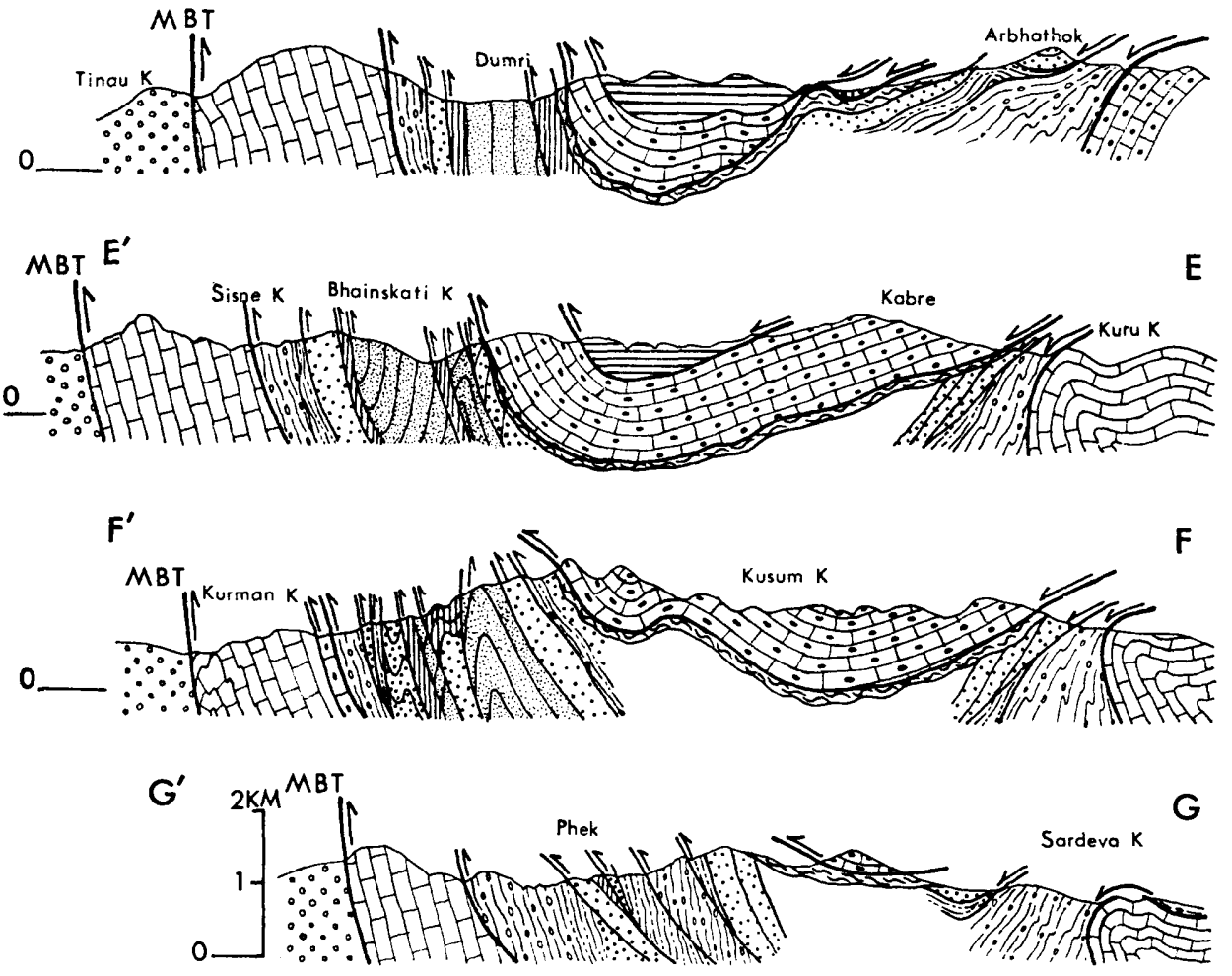

Fig. 22a. Profiles of the Tansen Synclinorium. 

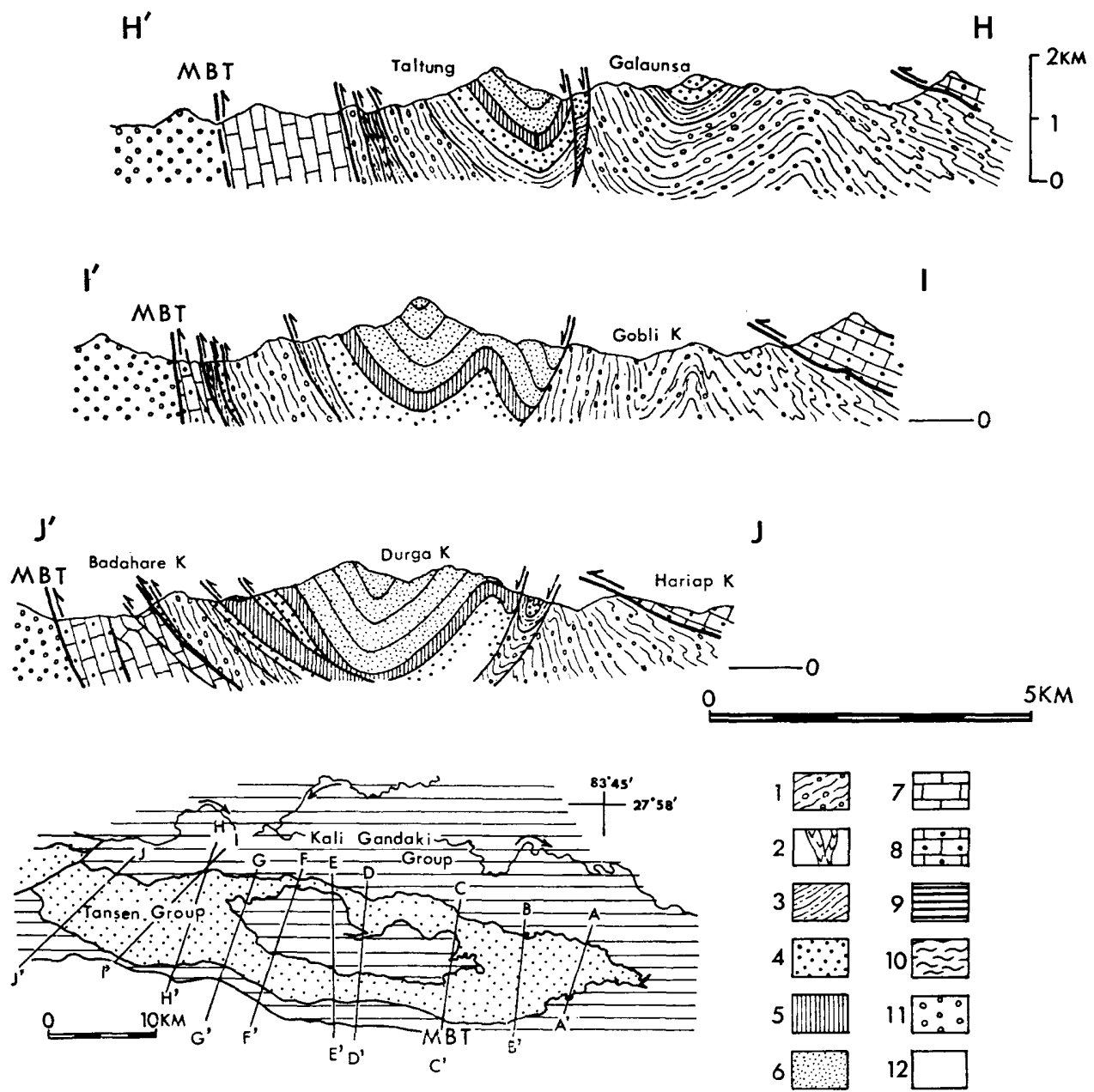

Fig. 22b. Profiles of the Tansen Synclinorium. Inserted map indicates section lines. 1, Sisne Formation; 2, Aulis Basalt; 3, Taltung Formation; 4, Amile Formation; 5, Bhainskati Formation; 6, Dumri Formation; 7, Karabari Formation; 8, Angha Khola Formation; 9, Heklang Phyllite of the Palpa Klippe; 10, rupture zone beneath the Palpa Klippe; 11, Siwaliks; 12, Quaternary.

on the geological map, Fig. 23, and profiles, Fig. 22, A-A' $\sim J-J^{\prime}$. Descriptions on the major tectonics of this area and the geologic features of the Kali Gandaki Group will be given in another paper. Herein the structural features of the Tansen Group are mentioned.

\section{A. Boundary faults between the Tansen Group and the Kali Gandaki Group}

The Tansen Group is bounded on all sides by a thrust fault against the Kali Gandaki Group. Its original stratigraphic relationship to the Kali Gandaki is, however, thought to have been an unconformity, a remnant of which is recognized only in the Besarka Outliers mentioned on page 35 . 
The boundary fault along the southern margin runs for the most part between the Sisne Formation of the Tansen Group and the Kerabari Dolomite of the Kali Gandaki except for the southeastern extremity and the southwestern tract, where the Taltung and Amile Formations are respectively in direct contact with the Kerabari. The fault steeply dips north in general, but moderately in the southeastern extremity and the southwestern tract of the Tansen Synclinorium. When the fault is steep, it is nearly parallel to the bedding planes of both the adjoining formations (Fig. 22a), and is usually accompanied with a fault gouge or a sheared zone as much as 20 to $50 \mathrm{~cm}$ wide, in places up to $2 \mathrm{~m}$ as seen in the Tinau and the Sisne river area. On the contrary, when the fault dips moderately it cuts the bedding planes obliquely (Fig. 22, G-G', J-J') and is represented by a sharp plane with only slight shearing of the neighbouring rocks.

The northern boundary fault of the Tansen Synclinorium is varied in attitude in places. In the eastern area it is represented by a sharp thrust plane dipping north at angles as low as $15^{\circ}$ to $20^{\circ}$, and the Ramdighat Slate of the Angha Khola Formation thrust directly upon the Sisne Formation (Fig. 22, A-A', $\left.B-B^{\prime}\right)$. To the west this thrust turns to dip south steeply at $45^{\circ}$ to $90^{\circ}$ and further to be inverted dipping to the north accompanying the reversed flank of the fold of the Angha Khola or the Kerabari Formation. In the western tract the nothern boundary is again manifested by a gentle, northerly dipping thrust. A notable feature of the northern boundary fault is that the fault plane is almost always sharp, neither fault gouge nor breccia being associated.

The Kali Gandaki Group on the north side of the Tansen Syclinorium is strongly folded and seems to show a large recumbent fold with a southerly verging axial plane at angles of $10^{\circ} \sim 20^{\circ}$. In particular, the Ramdighat Slate exposed in the eastern tract and a little west central tract demonstrate intense, recumbent, isoclinal folds of various scales. These folds can be well observed in the tributaries of the Angha river, and there, with respect to the boundary fault, even such an anomalous relation that the Sisne diamictites lie upon the Ramdighat with a rupture plane that dips south at angles $10^{\circ} \sim 15^{\circ}$ was locally seen. This inconsistent inclination of the thrust probably represents part of south-side-up inverted limb of a subsidiary recumbent fold of the two formations in question.

\section{B. Structural relationship between the Palpa Klippe and the sub. jacent Tansen Group}

The central part of the Tansen Synclinorium is occupied by a Klippe of the Kali Gandaki Group, herein newly named Palpa Klippe, that lies upon the Tansen Group with a remarkable rupture zone. This klippe forms a large, about $20 \mathrm{~km}$ long eastwest and $6 \mathrm{~km}$ wide northsouth, approximately doubly plunging, gentle synform. It consists of almost concordantly disposed duplex thrust sheets comprising the partly inverted Bajadi Purple Phyllites below and the Heklang Green Phyllites and Bajadi Purple Phyllites above, the latter being present only in the eastern half area. 
The boundary thrust between the Palpa Klippe and the subjacent Tansen Group is distinctly marked by a zone of sheared rocks as much as $10 \mathrm{~m}$ to more than $100 \mathrm{~m}$, in places up to $200 \mathrm{~m}$ thick. The sole of the Kali Gandaki Klippe is, however, well defined by a sharp plane, and the crushed part at the base is no more than a few tens of centimeter thick, so that the Kali Gandaki rocks maintain the original bedding planes at a short distance away from the thrust plane.

On the contrary, the rocks of the footwall, that is, of the Tansen Group are so strongly sheared and crushed as to form melange or tectonite that is composed of pervasively scaly-cleaved, argillaceous rocks containing usually lozenge-shaped to lenticular blocks and slices of sandstones of various sizes, ranging from a few millimeters to several tens of meter. Large tectonic slices as much as $60 \mathrm{~m}$ thick and $400 \mathrm{~m}$ long are found. In such blocks and slices original stratification planes are well preserved. There are many bands and streaks along which the rocks have been pulverized to a fine-grained gouge.

As is shown in the geological map (Fig. 23) and profiles (Fig. 22), the Palpa Klippe thrusts directly upon the Amile Formation for the greater part, except for the southeastern and the eastern extremities, where the Klippe is in contact with the Bhainskati and the Dumri Formation, respectively. This implies that, under the major portion of the Klippe, the whole sequence of the Dumri and the large part of the Bhainskati were scraped out or converted into the rocks of the melange zone. As a matter of fact, the inclusions of the melange zone are chiefly of the Bhainskati and the Amile Formation, although those in the eastern part have not been examined because of poor exposures. The Bhainskati and Amile rocks are easily disernible even in small pieces on account of their distinct lithologies; large blocks containing the Bhainskati molluscan fossils, boudinaged quartzose sandstones of the Amile Formation are commonly observed. The intensely sheared argillaceous matrix seems to have been originated from black shales of the Bhainskati. A good exposure showing the relationship between the Palpa Klippe and the subjacent rocks is seen at Kalang in the upper reaches of the Bhainskati river.

The crushed zone mentioned above is less resistant to weathering, so that the rocks of the zone easily lose coherency and tend to occur landslides.

\section{Geologic structure of the Tansen Group}

The Tansen Group forms an approximately doubly plunging synclinorium and is interpreted to basically represent a southern normal limb of a large recumbent syncline which seems to form a counterpart to a recumbent anticline of the Kali Gandaki Group on the north side of the Tansen Synclinorium as shown in Fig. 21. This interpretation seems to be warranted by the presence of the Sisne Formation, the lowest part of the Tansen Group, that rests on the Kerabari Dolomite, in the Pindi river area $7 \mathrm{~km}$ to the north of the Kali Gandaki river on the outside of the mapped area. Thus this large recumbent fold seems to have a wave length attaining $20 \mathrm{~km}$ and an amplitude up to $10 \mathrm{~km}$, and the Tansen Synclinorium itself has a half wave-length of about $7 \mathrm{~km}$. 


\section{Folds}

The Tansen Group is moderately folded with axes which trend approximately eastwest in the eastern tract and northwest in the central and western tracts. The folds are essentially of open, asymmetrical chevron-type usually with interlimb angles ranging from $70^{\circ}$ to $90^{\circ}$, rarely up to $70^{\circ}$ to $120^{\circ}$. The southern $\mathrm{limb}$ is longer than the northern limb and have a gentle inclination. The axial planes of the folds generally dip north steeply, except for the northern flank of the central area (see Fig. 22b $\mathrm{H}-\mathrm{H}^{\prime}, \mathrm{I}^{\prime} \mathrm{I}^{\prime}$ ), where the folds possessing a vertical to steeply northerly dipping axial planes are recognized. At least four orders of folds were discriminated; the first and the second order have a wave length of 3 to $5 \mathrm{~km}$ and 1 to $1.5 \mathrm{~km}$, respectively, and an amplitude of 1 to $1.5 \mathrm{~km}$ and 0.5 to $1 \mathrm{~km}$, respectively. The folds of the third and the fourth order exhibit a wave-length of 200 to $400 \mathrm{~m}$ and 20 to $40 \mathrm{~m}$, respectively. The folds of the third and fourth orders were not observed in the Dumri Formation, the top beds of the Tansen Group, whereas they are commonly developed in the Amile Formation. Therefore, it is estimated that the folding becomes more complex in the deeper part than in the surficial part. However, in these folds the thickness of beds are rather uniform and do not change remarkably in every portion of a fold, so that flexural-slip along bedding planes must have been predominant during the folding of the Tansen Group.

\section{Faults}

In the southern flank of the central and western areas of the Tansen Synclinorium, the folds mentioned above are strongly modified by longitudinal faults parallel to the general strike of the Tansen Group. Namely, there the folds are much more acutely compressed as compared with those of the the eastern and western areas and of the northern flank of the Synclinorium, and are diagonally cut mostly along their southern limbs (Fig. 23). These faults are thought to have occurred essentially associated with the overthrusting of the Palpa Klippe stated before, because they are developed mostly in the frontal area of that Klippe.

The longitudinal faults are mostly of reverse sense, although they cannot be called thrust because of their steep dip. They occur along limbs of the folds, mostly along the southern limb and occur as bedding fault along the major lithological boundary surfaces of the formation rank. The bedding fault is especially noticeable at the base and the top of the Bhainskati Formation. This is probably due to the difference of lithic characters, in other words of competency of rocks, between the Bhainskati and the underlying Amile Formation and the overlying Dumri Formation. The longitudinal fault or bedding fault was also commonly recognized at the base of the Amile Formation. These faults dip north steeply at angles $45^{\circ}$ to $75^{\circ}$ and are often associated with a shear zone up to several meters.

In the southern flank of the Tansen Synclinorium in the central area, the Tansen Group constitutes an imbricate structure owing to the combination of the folds and the longitudinal reverse faults. Each formation of the Tansen Group 
is repeatedly exposed three or more times (six times at maximum) in narrow belts often bounded by faults (Fig. 22a, E-E' G-G'), although thinly sliced belts are not shown in the geological map and profiles.

One of the most prominent longitudinal faults in the northern flank of the Tansen Syclinorium is that between the Sisne Formation and the Taltung Formation in the north-eastern area. This fault is well exposed in the Purba river area, where it runs nearly parallel to bedding planes which dip moderately to the south and is accompanied by fault gouge as much as 2 to $5 \mathrm{~m}$ in width. It can be traced westward to the central area, and there the Taltung Formation is almost entirely truncated. Another distinct is the fault that bound on the south of the wide outcrops of the Dumri Formation in the Gobli river area. It extends northwest and southeastwards and obliquely truncates the Amile and the Taltung Formation. It dips south at nearly vertical to steep angles.

Besides the longitudinal faults, there are many transverse faults that diagonally transect the general strike of the Tansen Group. Two sets trending NE and NW are discriminated. These form a conjugate system, because intersecting relationship can be observed in outcrops. Some transeverse faults in the Bhinskati river area have a hirozontal displacement as much as $80 \mathrm{~m}$ or so, but the others are of too small displacement to indicate them in the geological map.

Flow cleavages are commonly developed in argillaceous beds of the Tansen Group, especially in those of the Sisne Formation. Even the uppermost part of the Dumri Formation is weakly cleaved at high angles to the bedding planes. The relationship between the cleavage and megascopic structures was not analysed adequately, but the axial plane cleavage is most predominant in the Tansen Group.

\section{Summary}

Rocks of the southern part of the Lesser Himalayas in the Tansen area, western Central Nepal, is grouped into two major divisions, the Kali Gandaki Group below and the Tansen Group above, which are separated by a profound unconformity.

The Tansen Group is about $2400 \mathrm{~m}$ thick and is divided into five formations, Sisne, Taltung, Amile, Bhainskati, and Dumri, in ascending order. It ranges in age from late Carboniferous to early Miocene.

The Sisne Formation comprises diamictite and black shale of glacial influence, and is correlated with the Boulder Beds of the Lower Gondwana in the Indian Peninsula and the Himalayan Range. The Taltung Formation begins with the basal conglomerate comprised of basalt and quartzite pebbles and is characterized by cyclic to rhythmic sedimentation of clastic rocks. Basalt lava flows, altogether attaining about $200 \mathrm{~m}$ in thickness, are intercalated at the basal part. Plant fossils obtained from the lower part indicate that the Taltung is correlated with the Upper Godwana Beds of late Jurassic to early Cretaceous age. The Amile Formation consists mainly of quartzose sandstone with ferruginous mottles and subordinate interbeds of siltstone and limestone containing poorly preserved marine fossils, and is correlated with the Upper Tal 
of the Kumaon Lesser Himalayas. The Bhainskati Formation overlies the Amile conformably, and is composed of black shale with many thin beds containing foraminifers, molluses and vertebrates in the middle part, and oolitic hematite and red-purplish and green, mottled shale in the uppermost part. This formation is referable to middle to late Eocene on the basis of foraminifers, and is correlated with the Kirtar Series of the Indian Peninsula. The Dumri Formation is a thick series of interbeds of thick sandstone and lesser amounts of green and purple shale. Sandstones become much predominant and massive up-sections. This formation is correlated with the Dagshai in India.

No intense diastrophism has been recognized throughout the sequence of the Tansen and Kali Gandaki Groups. All the formations are disposed almost parallel to one another. Only epeirogenic movement occurred and resulted in intermittent marine incursions and the disconformities under the Sisne, the Taltung, the Amile, and the Dumri Formation. Of these disconformities most prominent is that at the base of the Sisne, and a remarkable difference of lithofacies is recognized between the Sisne and the underlying Kerabari Dolomite. However, how large the time-stratigraphic gap between them is cannot be known. Within the sequence of the Tansen Group, Triassic to middle Jurassic and also probably Oligocene rocks are missing. The disconformity at the base of the Taltung is associated with thick beds of conglomerate and extrusions of the Aulis Basalt. These suggest that the epeirogenic movement at this time was accompanied by the disruption of the basement. The Tansen and the Kali Gandaki Group are as a whole referable to the deposits on a stable platform.

That the Mesozoic and Cenozoic beds of the Tansen Group are largely fluvial sediments is evidenced by the presence at many levels of red beds, shale-pebble conglomerate, sandstone and siltstone mottled with ferruginous matter, and carbonaceous beds often containing wood fragments. Marine beds occur in the middle part of the Amile and the main part of the Bhainskati, and are interpreted as intertidal to very shallow sea sediments. The Ritung Bioturbated Mudstone at the top of the Sisne Formation is also of marine sediments.

In view of sedimenary facies, each formation of the Tansen Group is intermidiate between the correlatives in the Indian Peninsula and those of the Higher Himalayas and the Punjab region of the western Lesser Himalayas.

Cross-bedding and imbrication of pebbles in many beds of the Sisne, Taltung and Amile Formations indicate a prevailing current direction from east to west and from south to north. This fact implies consistent supply of clastics from the peninsular part of India. Whereas those of the Dumri exhibit the current system from north to south. This change probably reflects the embryonic development of the Himalayas. In this concection, it should be noted that the Dumri became much greater in thickness and includes less matured and more massive beds as compared with the underlying Bhainskati and other formations.

The Tansen Group is embraced in a large, doubly plunging synclinorium which is separated by the boundary fault of reverse sense from the surrounding Kali Gandaki Group. It is folded with axes of the EW to NW-SE direction. The folds are of open, asymmetric chevron-type of a southerly vergence, and at least four orders of wave-length were discriminated. These folds are modi- 


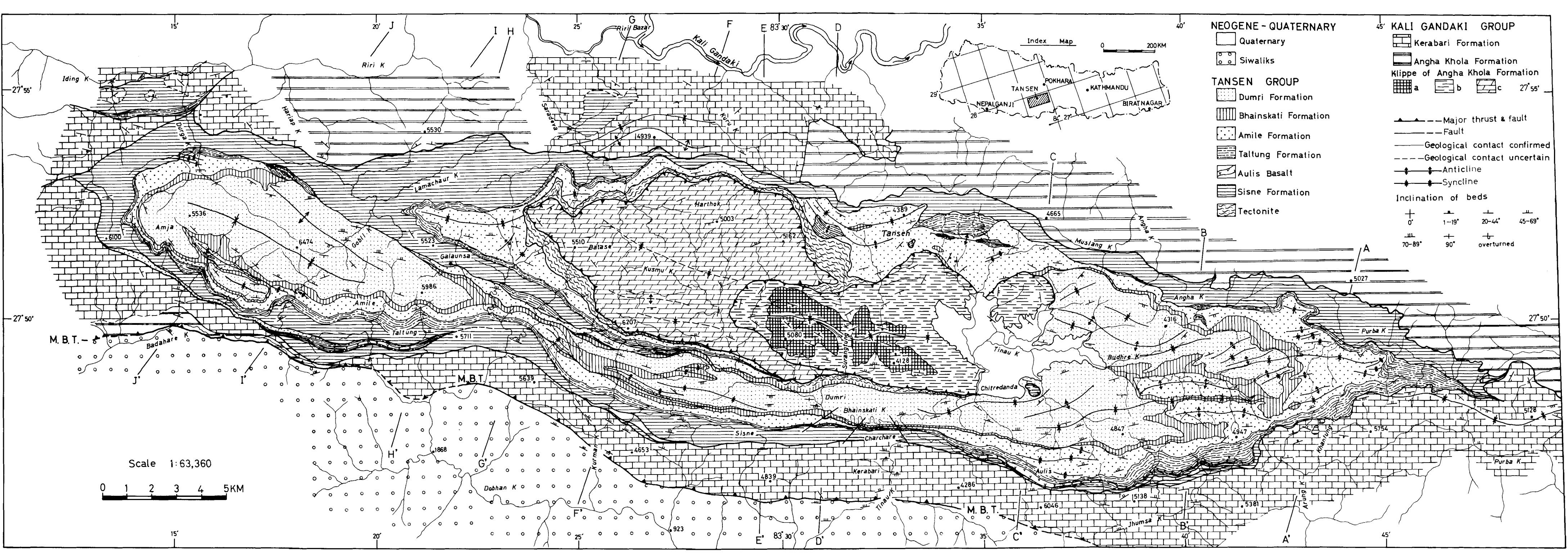

Fig. 23. Geological map of the Tansen area. 
fied by longitudinal faults, in particular strongly in the southern flank of the central area, where the Tansen Group forms an imbricate structure.

It is certain that the folding and reverse longitudinal faulting of the Tansen Group and the underlying Kali Gandaki Group were taken place after the deposition of the Dumri Formation of probably early Miocene age.

\section{Acknowledgement}

I am grateful to Professor B. M. Pradhan, Dr. M. P. Sharma, Dr. B. N. Upreti and other staffs of the Department of Geology, Trichandra Campus, Tribhuvan University, who have rendered me available facilities to work during my visit to the university. I wish to thank to Mr. J. M. Tater, the Dupty Director General of the Department of Mines and Geology, Ministry of Industry and Commerce, who kindly gave me every facility for this study, and also thank to all geologists in the Department of Mines and Geology, for their kind help and valuable discussion.

I am greatly indebted to Professor K. Kanmera of the Department of Geology, Kyushu University for his kind supervision and critical reading of the manuscript and also to the staffs of the Department of Geology, Kyushu University, for their encouragement and advice. Professor S. Sakagami, Geological Institute of Chiba University, Professor T. Kimura, Institute of Earth Sciences, Tokyo Gakugei University, Dr. K. Matsumaru, Department of Geology, Saitama University, Dr. I. Obata, Dr. T. Ueno, Dr. K. Uemura, Dr. Y. Tomida, Dr. T. Kase, Dr. K. Ono of the National Science Museum, kindly identified the fossil specimens at my disposal. All the geologists of the National Science Museum gave me useful suggestions. I deeply appreciate for their kind help and advice. I am much indebted to Professor H. Okada, Institute of Geosciences, Shizuoka University, for his advice and encouragement.

This work was financially supported by J.O.C.V. to whom concerned I am greatly indebted.

\section{References Cited}

Arita, K., Hayashi, D. and Yoshida, M. (1982): Geology and structures of the Pokhara- Piuthan area, central Nepal. Jour. Nepal. Geol. Soc., 2, Special Issue, 5-29.

ARITA, K. and YoshidA, M. (1982): Geological observations along motor road from Butwal to Ramdighat, central Nepal. Jour. Nepal. Geol. Soc., 2, Special Issue $51-58$.

BORDET, P. (1961): Recherches geologiques dans'l Himalaya du Nepal, region du Makalu. Edit. Cent. Nat. Rech. Sci. Paris, 275 p.

Frank, W. and Fuchs, G. R. (1970): Geological investigations in west Nepal and their significance for the geology of the Himalayas. Geol. Rdsch., 59, 552-580.

FUCHS, G. R. and Frank, W. (1970): The geology of west Nepal between the rivers Kali Gandaki and Thulo Bheri. Jahrb. Geol. Bundesanst., 18, 103 p.

Fuchs, G. (1980): The Lesser Himalayan Geology of west Nepal and its regional importance.; in VALDIYA, K. S. and BHATIA, S. B., (Eds). Stratigraphy and Correlations of Lesser Himalayan Formations. Hindustan Publ. Corp, Delhi, 
$163-173$.

Ganestan, T. M. (1972): Fenestellid bryozoa from the boulder slate sequence of Garhwal. Himalayan Geol., 2, 431-451.

GANsser, A. (1964): Geology of the Himalayas. John Wiley \& Sons, London, $289 \mathrm{p}$.

HAGEN, T. (1969) : Report on the geological survey of Nepal, 1, Preliminary reconnaissance. Denkschr. Schweiz. naturf. Ges., 86, 159 p.

Hashimoto, S., Ohta, Y. and Akiba, Ch. (Eds.). (1973): Geology of the Nepal Himalayas. Saikon Publ., Tokyo, 292 p.

JAIN, A. K. and DAS, A. K. (1973): On the discovery of Upper Palaeozoic bryozoans from Kameng District, Arunachal Pradesh. Curr. Sci., 42, 352-354.

Krishnan, M. S. (1982) : Geology of India and Burma (6th ed.), CBS Publ. \& Dist., Delhi, $536 \mathrm{p}$.

Mascle, G. H. (1980): Tectonic reconstruction of stratigraphy of Midlands in Central Nepal in the light of structural analysis.; in ValdiYA, K. S. BHATIA, S. B. (Eds). Stratigraphy and Correlations of Lesser Himalayan Formations. Hindustan Publ. Corp., Delhi, 191-197.

REMY, J. M. (1975) : An introduction to the Geology of the western Nepal. Himalayan Geol., 5, 280-301.

Sharma, C. K. (1977) : Geology of Nepal. Education Enterprises, Kathmandu, 164 p.

Sharma, C. K. (1980) : Stratigraphy of Lesser Himalayan formations of western and far western Nepal.; in Valdiya, K. S. and BhatiA, S. B., (Eds). Stratigraphy and Correlations of Lesser Himalayan Formations. Hindustan Publ. Corp., Delhi, 174-179.

SINGH, P. (1973) : A note on the fossiliferous Formation in Lesser Himalaya of Nepal and Bhutan. Himalayan Geol., 3, 372-380.

Stöcklin, J. (1980): Geology of Nepal and its Regional Frame. Jour. Geol. Soc. London, 137, 1-34.

Stöcklin, J. and BhattaraI, K. (1977) : Geology of Kathmandu area and Central Mahabharat Range, Nepal Himalaya. HMG/UNDP Mineral Exploration Project Report (unpublished). $86 \mathrm{p}$.

Tiwari, B. S. and Gupta, V. J. (1976) : Foraminifera from the Subathu Formation, Surkhet Vallery, Western Nepal. Himalayan Geol., 6, 209-220.

VAldiYA, K. S. (1980) : Geology of Kumaun Lesser Himalaya. Wadia Institute of Himalayan Geology, Dehra Dun, India, $291 \mathrm{p}$.

VALDIYA, K. S. and BHATIA, S. B., (Eds), (1980): Stratigraphy and Correlations of Lesser Himalayan Formations. Hindustan Publishing Corporation, Delhi, 330 p.

Wadia, D. N. (1975) : Geology of India (4th. ed.). Tata-McGraw Hill Publ. Co. New Delhi, 508 p. 